\title{
The development and typology of number suppletion in adjectives
}

\section{Nurmio, Silva Mikaela}

2017-07-14

Nurmio , S M 2017 , ' The development and typology of number suppletion in adjectives ' , Diachronica , vol. 34 , no. 2 , pp. 127-174 . https://doi.org/10.1075/dia.34.2.01nur

http://hdl.handle.net/10138/309085

https://doi.org/10.1075/dia.34.2.01nur

unspecified

acceptedVersion

Downloaded from Helda, University of Helsinki institutional repository.

This is an electronic reprint of the original article.

This reprint may differ from the original in pagination and typographic detail.

Please cite the original version. 


\title{
The development and typology of number suppletion in adjectives*
}

\author{
Silva Nurmio \\ Dublin Institute for Advanced Studies \\ silva@celt.dias.ie
}

This paper looks at the cross-linguistically rare phenomenon of suppletion in number in adjectives. I consider how such suppletion arises by looking at six known examples with a special focus on the Brittonic languages (Breton, Cornish and Welsh) which are discussed as an extended case study. Three generalisations are suggested on the basis of the typological study. First, adjectives denoting size ("small" and "big") are at the centre of this phenomenon. Second, where the etymology of the adjectives is known, the plural member of the suppletive pair for "small" develops from a lexeme denoting something having been divided into or consisting of small parts. These lexemes can also be used with some singular nouns and in such cases their reference is to the component structure of the referent. Finally, adjectives with number suppletion tend to mark plural number consistently in environments in which plural marking is otherwise optional or rare.

Keywords: suppletion, adjectives, grammatical number, agreement, inflectional morphology, Brittonic languages

\section{Introduction}

Suppletion in number in adjectives is extremely rare. As an example, consider the following singular/plural noun phrases from Swedish where the adjective "small" is suppletive (liten in the singular, små in the plural).
a. en liten flicka
a small girl
"a small girl"
$\begin{array}{llll}\text { b. } \quad \text { två } & \text { små } & \text { flickor } \\ & \text { two } & \text { small.PL } & \text { girl.PL }\end{array}$
"two small girls"

In this paper I follow Mel'čuk's (1994: 339) definition of suppletion:

Two linguistic signs are in relation of suppletion if the semantic difference between them is maximally regular (i.e., it is grammatical= inflectional or derivational) while their formal difference is maximally irregular (i.e., it is not covered by any alternation).

The kind of suppletion dealt with in this article is inflectional suppletion according to number (singular/plural) and one where the suppletive elements belong in origin to two different

\footnotetext{
* I would like to thank Anders Jørgensen, Barry Lewis, Lars Nooij, Paul Russell and three anonymous reviewers for Diachronica. Any remaining errors are mine alone.
} 
lexemes (for a detailed introduction to different types of suppletion and terminology, see Veselinova 2006: 1-31).

Suppletion in the comparison of adjectives is a well-known and cross-linguistically common phenomenon, e.g. English bad, worse, worst. A search for suppletion in adjectives in the Surrey Suppletion Database (Brown et al. 2003) returns many examples of adjectival comparison, one instance of suppletion in number (discussed below) and one of suppletion between the short and long forms of a Russian adjective. It should be noted, however, that while many languages have suppletion in the comparison of adjectives, this is crosslinguistically limited to very few lexemes. In Bobaljik's (2012: 109) study of just over 300 languages, suppletion is most commonly found with "good" and "bad", followed by "big" and "small". When we look at number suppletion in adjectives, however, only "big" and "small" occur and I discuss possible reasons for this below. The rarity of suppletion in adjectives where it does not involve comparison was noted by Mel'čuk (1976: 68): "Cases when there are suppletive adjectives opposed according to gender, number or case are, by all evidence, extremely rare." In fact, there are no known instances of suppletion according to gender in adjectives according to Mel'čuk (1994: 390) and I am not aware of any examples in more recent literature. ${ }^{1}$

The phenomenon of number suppletion in adjectives was first noted for the Mainland Scandinavian languages (Danish, Norwegian and Swedish; see Ljunggren 1944), and only recently has attention been drawn to other parallels. The Scandinavian example is also discussed by Hippisley et al. (2004), Corbett (2007: 32), and Börjars \& Vincent (2011). Corbett (2007: 32) also briefly mentions adjectival suppletion in Mara (Northern Territory, Australia). Jørgensen (2012) was the first to my knowledge to demonstrate number suppletion in adjectives in medieval Breton and Cornish, while Maiden (2014) drew attention to Megleno-Romanian dialects. To this inventory I now propose to add suppletion in Tariana (Arawak, Brazil) and Menominee (Algonquian, US). The Mainland Scandinavian languages are treated as a group due to their close relationship to one another, and likewise Breton and Cornish are taken together as one example. We have, therefore, six known language groups or individual languages which have number suppletion in adjectives between singular and plural. Welsh, a sister language of Breton and Cornish, also has two adjectives for "small" one of which is mostly restricted to use with plurals and non-count singulars. This parallels the situation in the languages with number suppletion, yet I show in section 3 that a suppletive paradigm has not arisen in Welsh.

Number suppletion in adjectives was used by Börjars \& Vincent (2011) to shed light on the question of how suppletion first arises in a language, which is a fairly unexplored area. Most work on suppletion (e.g. Hippisley et al. 2004) has been focused on how and why suppletive forms persist diachronically and resist regularization, which is attributed to factors such as frequency. Börjars \& Vincent, on the other hand, are interested in the pre-conditions for suppletion and use the Mainland Scandinavian languages as a case study. Their study concludes that the driving force behind suppletion is semantics, namely semantic overlap between two lexemes, one dominant and one recessive, where the paradigm of the recessive lexeme donates into the paradigm of the dominant one. Despite partial semantic overlap, the

\footnotetext{
${ }^{1}$ In his earlier article Mel'čuk (1976: 68) mentions the Classical Greek numeral $\varepsilon \tilde{i} \varsigma$ (masc.)/ $\mu i \alpha$ (fem.) "one" with the implication that he regards these as possible examples of gender suppletion in adjectives, but includes no further discussion or an explanation of whether numerals and adjectives should be considered together. These forms reflect the $e$-grade and zero grade respectively of one of the two Indo-European stems for "one", namely *sem- (the other stem being *oy-) (Sihler 1995: 404406). In other words, the masculine and feminine forms are historically related, although they appear suppletive synchronically.
} 
dominant lexeme is more general in meaning while the recessive lexeme is more specific. Frequency is an indirect factor in the sense that "elements with general meaning are more frequent" (Börjars \& Vincent 2011: 245). Their study builds on Maiden (2004) who argues that lexical synonymy is the main cause of suppletion, and this is argued again in Maiden (2014). The main contribution of the present paper is to reconsider and refine the theories in Börjars \& Vincent (2011) and Maiden $(2004,2014)$ and apply them to the six languages or language groups reviewed here. I also suggest that we should consider number suppletion in adjectives and verbs together as there are significant parallels. The diachronic case study on Welsh completes the typological description of the Brittonic language group and also demonstrates that a language can meet the pre-conditions for adjectival number suppletion, yet no suppletive paradigm need arise.

I begin by introducing the morphosyntax of adjectives in the Brittonic languages (section 1.1) and the suppletive paradigms in Breton and Cornish (section 1.2) before turning to a cross-linguistic examination of the known examples of number suppletion in adjectives (section 2). Sections 2.2-2.4 discuss the historical development of this type of suppletion and some theoretical implications. Section 3 is a case study on Welsh and I argue that the morphosemantics of bychan/bach "small" on the one hand and mân "small" on the other can be said to fulfil pre-conditions for suppletion, although a suppletive paradigm is not actualised. I also consider the antonyms mawr "big" and bras "thick; large", whose semantic relationship partially parallels that of the pair bychan/bach and mân "small" and provides further evidence for the typological generalisation that for adjectives denoting size there are often two partially overlapping lexemes.

\subsection{The morphosyntax of adjectives in the Brittonic languages}

In Breton, Cornish and Welsh, adjectives regularly follow the noun they modify, although a few adjectives can be placed before the noun. In Welsh, adjectival agreement in attributive and predicative positions is optional in all periods apart from one adjective, arall "another, other", pl. eraill, which virtually always agrees in number with the head noun. In Middle Welsh, there is a small group of adjectives which have a strong preference for number agreement, while others show a less clear pattern. The first group includes bychan "small", pl. bychain. ${ }^{2}$ Middle Welsh translation texts (mostly from Latin, some from French) should be treated separately, since the prevalence of adjectival agreement in noun phrases is much higher in these than in native texts (Nurmio 2015: 161-187). Adjectival agreement declines towards the Modern Welsh period; for examples of agreement in different dialects, see Thomas (2000: 469-470, 472-473). Plural adjectives often survive in phrasal compounds, e.g. bysedd cochion "foxgloves", lit. "red.PL fingers", see Awbery (2014). A small group of adjectives have feminine forms formed by vowel alternation, e.g. gwyn (masc.), gwen (fem.) "white". Gender agreement, like number agreement, declines towards Modern Welsh,

\footnotetext{
${ }^{2}$ There are a number of ways of forming the plural of nouns in Breton, Cornish and Welsh, and a smaller range is available for adjectives. The following are examples of Welsh nouns but the processes are shared by the three languages: (i) addition of a variety of plural suffixes, of which - $a u$ is the commonest e.g. siop "shop", plural siopau; (ii) vowel alternation e.g. car "car", plural ceir; (iii) as part of a pair of a monomorphemic plural base (also called 'collective'), where the singular adds a singulative suffix e.g. adar "birds", singulative aderyn (see Nurmio (forthcoming) and below); or (iv) a combination of these processes e.g. cadair "chair", plural cadeiriau with the addition of the suffix $i a u$ and vowel alternation. Adjectives usually form their plural by adding the suffix -ion; some also have plurals formed by vowel alternation, especially in Welsh. For further details, see Watkins (1961: 145-154), Awbery (2009: 387-389) and Willis (2009: 133-136).
} 
although it is still fairly common with a small group of adjectives (see Schumacher 2011: 134 and Awbery 2009: 389-390).

Handbooks on Middle Breton and Middle Cornish state that adjectival agreement is lost and that plural adjectives only occur when used substantivally. The only exception given for Middle Breton is quaez/kaezh "poor", pl. queiz/keizh which can agree in attributive position, e.g. an Bretoned queyz "the poor.PL Bretons" (see Lewis \& Piette 1966: 14; Hemon 1975: 47, 66; Schrijver 2011a: 392 and Williams 2011: 309). There are also a few uncertain but possible examples of attributive and predicative adjectives agreeing in the plural in the Old Breton glosses and the Middle Cornish plays, and some also survive in petrified form in Cornish place names, see Bauer (2008), Padel (1979-1980), and Nurmio (2015: 168-169) for discussion of these. ${ }^{3}$ The basic pattern, however, is for adjectives modifying plural head nouns to remain unchanged, with the notable exception of MB bihan and MC byhan "small" and their suppletive plural forms discussed below. This is an important point for the discussion that follows; attributive agreement in Breton and Cornish is virtually lost by the medieval period and this makes the adjectives for "small" all the more noteworthy, since they retain number agreement consistently. This raises the question whether Middle Breton and Middle Cornish have a singular/plural paradigm for adjectives at all. I would argue that they do, partly due to the admittedly few examples still attested and partly because of the existence of plural adjectives used as nouns, e.g. en cliffyen "the sick (people)" from singular claff "sick" (Hemon 1975: 66). These could also be analysed as containing a zero head noun ("people" in the example given, since pluralised adjectives usually denote humans), although this is debatable and beyond the scope of the present discussion. In Breton and Cornish, adjectives do not have separate gender forms in any period.

\subsection{Suppletive paradigms in Breton and Cornish}

The Breton and Cornish adjectives with number suppletion are, along with their Welsh cognates (all translations of Welsh words are from $G P C$ ): ${ }^{4}$

a. MB bihan (variant spellings byhan, bian) "small"

b. MC byhan (byan, by (h)en) "small"

c. W bychan (masc.)/bechan (fem.), pl. bychain "small",5
a. MB munut "small"
b. MC munys "small",
c. W munud "courteous, civil, courtly; ?generous; ?polished, smooth; ?shattered, broken". It can also be used as a noun with the meanings "courtesy, gentility, good

\footnotetext{
${ }^{3}$ Middle Breton refers to the language from the end of the eleventh to the middle of the seventeenth century, although there are few texts of any length until the fifteenth century (see Schrijver 2011a). Middle Cornish refers to the language from the twelfth to the end of the sixteenth century, although the bulk of texts is from the fourteenth century and later (see Williams 2011). Middle Welsh refers to the language from the twelfth to the end of the fourteenth century (see Schumacher 2011).

${ }^{4}$ I give citation forms in the modern orthography even for Middle Breton, Cornish and Welsh, following the convention of the main dictionaries. For quotations from texts, the orthography of the original is maintained.

${ }^{5}$ I will gloss these adjectives simply with "small" from now on, since the semantic difference between the English adjectives "small" and "little" is not relevant to the discussion.

${ }^{6}$ The change of a final dental to /s/ is regular in Middle Cornish.
} 
manners, etiquette; ?generosity; demeanour, manner; ceremony; gesture, motion, sign, nod, a beckoning, movement, antic; (facial) expression, grimace"

The adjectives in (3) are borrowings from Latin minütus, the past participle of minuere which has a range of meanings centred around "become/make small"; full definitions are given in (4). Whether the Brittonic adjectives all derive from a single borrowing of minütus into Brittonic, or whether it could have been borrowed separately into the sister languages in a later period, is discussed below.

a. Lewis \& Short (1897), s.v. minuo: as transitive (a) (rare and mostly poet.) to chop into small pieces (b) to lessen, diminish, lower, reduce, weaken, abate, restrict; as intr. (a) to diminish, grow less; hence past participle minūtus "little, small, minute; petty, paltry, insignificant"

b. $\quad D M L B S$, s.v. minuere: 1 (intr) to become smaller b (trans) to reduce in size or extent, make smaller; 2 to reduce in amount, number or value, make less ... 5 to cut into smaller pieces, mince ... 9 (past participle as adj.) small in size, amount, or value; 10 less important, with little authority or power; 11 minute, executed with attention to detail

Jørgensen (2012) shows convincingly that Middle Breton and Middle Cornish have suppletion in the paradigm of the adjective "small" between singular and plural: MB bihan and MC byhan are used with singulars and singulatives, while MB munut and MC munys are used with plural, morphological collective, singular aggregate and group nouns.

'Morphological collective' refers to nouns in the Brittonic languages with an unaffixed base form denoting many (e.g. W adar "birds") and a singulative denoting one formed with the suffixes W -yn (masc.)/-en (fem.) and B, C -en(n), e.g. W ader-yn "a bird". 'Aggregate' is used instead of the term 'mass' since the Brittonic languages have two kinds of nouns which can be described as mass nouns. These are 'proper' mass nouns which are fully uncountable and mostly denote liquids, and nouns denoting aggregates like sand and grains whose grammatical behaviour is somewhere between 'proper' mass nouns and collectives; for example, they can take the singulative suffix for a unit meaning. See Nurmio (forthcoming) for a more detailed discussion of these noun categories.

The following Breton and Cornish examples are from Jørgensen (2012) apart from the Middle Cornish example in (5d) which is my addition: ${ }^{7}$

\footnotetext{
${ }^{7}$ The Brittonic languages have a system of initial consonant mutations triggered on certain consonants by items such as the definite article and numerals. The most common of these, and the only one relevant to the present discussion, is known as soft mutation (sometimes 'lenition') whereby in Modern Breton /p t k b d g gw m/ (orthographically the same) become /b d g v z h w v/

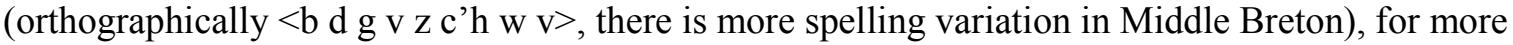
details see Ternes (2011: 458-461). Soft mutation is triggered on adjectives following feminine singular nouns (in all three languages) and adjectives following plurals of masculine nouns denoting humans (only in Breton and Cornish), as can be seen in example (5e) where B munut becomes vunut following tud "people". Soft mutation also occurs on the noun if the usual order noun + adjective is reversed, as seen in examples in section 3. The Cornish and Welsh soft mutation patterns are in part identical to Breton with some differences. In Middle and Late Cornish, /p t k b d g m t $\mathrm{f} /$ (orthographically $<\mathrm{p} \mathrm{t} \mathrm{c/k} \mathrm{b} \mathrm{g} \mathrm{m} \mathrm{ch}>$ ) become /b d g v $\varnothing / \mathrm{w} \mathrm{v} \mathrm{d} /$ (orthographically $<\mathrm{b} \mathrm{d} \mathrm{g} \mathrm{v/f} \mathrm{th}$ zero/w v g/j>), see Williams (2011: 304-305). In Modern Welsh, /p t k b d g m $\mathrm{rr}_{\mathrm{o}}^{\mathrm{h}} /$ (orthographically
} 

a. $\quad$ MB vn leufr bihan "a small book"
MB vn guezen bian "a small tree"
MC the flogh byhan "your small child"
b. MB hevnet munut "small birds"
MC taklow minniz "small things"
c. $\quad$ MB frouez munut "small fruit(s)"
d. $\quad$ MB glau munut "small rain (= light rain)"
MC mar venys avel skyl brâg "as small as malt dust" (see Norris 1859: 206)
e. Modern literary Breton an dud vunut "the small people; the humble people"

The examples in (a) are singular count nouns (leufr "book", flogh "child") and a singulative formed from the collective gwez "trees". (b) shows the use of MB munut and MC munys with plurals although there are some examples of bihan/byhan with plurals as well, as discussed below. MB munut is also used with morphological collectives as seen in (c); I am not aware of any Cornish examples of this type. In (d) munut and munys are used with the singular aggregate nouns glau "rain" and skyl "dust, waste". (e) is included to demonstrate the use of MB munut with singular group nouns, i.e. nouns which are singular in form but which denote a group and can have plural agreement and anaphora (Corbett 2000: 188-191, see also Nurmio (forthcoming) for these nouns in Welsh); no medieval examples of these types of nouns are given by Jørgensen. ${ }^{8}$ The following table from Jørgensen (2012) shows the type of nouns modified by Breton bihan and munut in his sample, which includes medieval Breton (phase 1) and early Modern and Modern Breton (phase 2). This table is a summary of several more detailed ones showing the number of tokens in each part of the sample; see Jørgensen (2012) for these.

Table 1. Types of nouns modified by Breton bihan and munut.

$\langle\mathrm{p} \mathrm{t} \mathrm{c} \mathrm{b} \mathrm{d} \mathrm{g} \mathrm{m} \mathrm{ll} \mathrm{rh}>$ ) become /b d g v ð $\varnothing \mathrm{v} \mathrm{l} \mathrm{r/} \mathrm{(orthographically}\langle\mathrm{b} \mathrm{d} \mathrm{g} \mathrm{f} \mathrm{dd}\rangle$ zero $\langle\mathrm{f} 1 \mathrm{r}\rangle$, spelling variation occurs in Middle Welsh), see Awbery (2009: 376-381).

${ }^{8}$ Further research is needed on the behaviour of bihan/byhan and munut/munys in numeral phrases although this is beyond the scope of this paper. Jørgensen (2012) quotes the example diou mer'ch bian "two small girls" with the singular form of the adjective (from the seventeenth century). In the Brittonic languages, numerals above "one" are regularly followed by the noun in the singular (see Nurmio \& Willis 2016 for a discussion of Welsh). In Middle Welsh, those adjectives that have plural forms agree in the plural in numeral phrases, but by Modern Welsh the agreement pattern shifts and the adjective has to be singular (Willis 2014). 


\begin{tabular}{|c|c|c|}
\hline Attributive adjectives & 1. & 2. \\
\hline $\begin{array}{c}\text { text } \rightarrow \\
\text { type of noun } \downarrow\end{array}$ & $\begin{array}{l}\text { Quiquer, Kerampuil, JV, } \\
\text { BD, Bernard? }\end{array}$ & $\begin{array}{l}\text { Euzen Gueguen, Modern Breton } \\
\text { and Vannetais dialect }\end{array}$ \\
\hline singular, singulative & bihan & bihan \\
\hline $\begin{array}{l}\text { singular aggregate and } \\
\text { group nouns }\end{array}$ & munut & munut $\sim$ bihan \\
\hline plural, collective & munut & $\begin{array}{l}\text { bihan (munut still in fixed } \\
\text { phrases) }\end{array}$ \\
\hline
\end{tabular}

Texts: Quiquer of Roscoff, Nomenclator [a Latin-French-Breton thesaurus], 1633; Gilles de Kerampuil, 1570s; JV= Buhez Genovefa a Vrabant, mid-17 ${ }^{\text {th }}$ c.; BD= Ar Varn Diwezhañ, late 17 th-early $18^{\text {th }}$ c.?; Bernard ar Spered Santel, 1640s; Euzen Gueguen, early $17^{\text {th }} \mathrm{c}$.

Middle Breton shows clear suppletion: bihan after singular nouns and singulative nouns, munut after plural nouns and collectives as well as singular aggregate and group nouns. The system collapses towards Modern Breton where bihan can be used with all nouns while munut is confined to fixed phrases mostly with aggregates, e.g. glav munut "light rain" and sukr munut "fine sugar". 9 Cornish shows a similar pattern where byhan is used with singulars and munys with plurals, although byhan is also sometimes found with plurals (two examples from Bewnans Meriasek [BM]).

Table 2. Types of nouns modified by Cornish byhan and munys (from Jørgensen 2012).

\begin{tabular}{|c|c|c|}
\hline $\begin{array}{c}\text { The Cornish corpus, } \\
\text { attributive use }\end{array}$ & byhan & munys \\
\hline Singular noun & 20 & $1 ?(\mathrm{BM})$ \\
\hline Plural noun & $2(\mathrm{BM})$ & 7 \\
\hline
\end{tabular}

This table includes Middle and Late Cornish texts; the table is simpler than that for Breton due to the smaller number of extant texts. The uncertain singular example with munys with a singular noun is pe dyth munys kewsovghwy "if it be a little dyth that you.PL speak" (Bewnans Meriasek). This is the only attestation in Cornish, and indeed any Brittonic language, of $d y t h$, usually taken to mean "a saying" (borrowed from Latin dictum). Although morphologically singular, dyth could perhaps have carried a plural sense ("that which is said", hence "words") which could license the use of munys. Words denoting that which is said can be ambiguously singular or plural; consider Latin verba "words, expressions" and dicta "things said, words" (plurals of verbum and dictum) which are often used more generally for "language, discourse, conversation" (Lewis \& Short 1897: s.vv. verbum, dīco). Since we lack further examples of $d y t h$, we cannot place much weight on this single example with munys. Middle Cornish, then, has essentially the same pattern as Middle Breton.

Breton bihan and munut and Cornish byhan and munys are suppletive in number synchronically in the medieval period. As seen above, the Breton paradigm falls apart in the

\footnotetext{
${ }^{9}$ I propose to analyse these as lexicalised phrases rather than as evidence of continued productive use of munut with aggregates. To posit the latter would amount to saying that munut originally denoted "composed of small parts" (as discussed in 2.2), broadened to mean "small" more generally in Middle Breton, and then restricted its meaning to "composed of small parts" again by Modern Breton. It seems more likely that phrases like glav munut have simply become lexicalised.
} 
later language, while Cornish became extinct by the end of the eighteenth century, so we do not know what the fate of the suppletive paradigm would have been. The two examples of byhan with a plural noun in Table 2 may be indications of the suppletive paradigm beginning to fall apart in Cornish, too.

Welsh is considered in section 3 where I initially look at the synchronic medieval state while also taking a broader diachronic look at the development of the Welsh adjectives for "small". While W bychan "small" matches its Breton and Cornish cognates in meaning in all periods, $\mathrm{W}$ типиd has a different meaning and distribution from its cognates. There is also a form bach "small" which is likely related to bychan and has no Breton or Cornish equivalents. Furthermore, Welsh has another adjective mân "small" with no Breton or Cornish cognates but whose semantics and usage resemble those of munut and munys as well as other "component-size" adjectives in the languages or language groups discussed in the next section.

(6) W mân (a) small, little (in size), (b) fine, thin, finely woven, not rough or coarse (of thread, \&c.); fine (of sieve or mesh); fine (of sand, salt, ashes, \&c.), ground small (of flour, \&c.); refined, elegant, (c) unimportant, trifling, insignificant; of inferior position, rank, \&c. (of person, also of court, \&c.); minor (of ailment), not very serious (of illness, fault, sin, \&c.)

\section{The typology and historical development of number suppletion in adjectives}

\subsection{Languages with number suppletion in adjectives}

I begin with attested examples of number suppletion in adjectives in addition to the Brittonic examples already mentioned. The sections that follow look at the reasons why this kind of suppletion is rare (2.2) and how adjectives which solely or predominantly select plural heads arise cross-linguistically (2.3 and 2.4). A shared tendency in three of the languages or groups under discussion (Mainland Scandinavian, Megleno-Romanian, Brittonic) is that they can denote component size (a term taken from Maiden 2014: 41). For example, a referent such as a forest can be "small" or "big" in two ways; small/big in its circumference or in the sense that the trees which make up the forest are small/big. In the latter instance "small" and "big" refer to component size. With plural nouns the situation is different since their referents always have component structure, and I return to this point in 2.4.

As discussed in the introduction, number suppletion with "small" in the Mainland Scandinavian languages was noted as early as Ljunggren (1944). Since then, three other languages or language groups have entered the typological picture, to which I now propose to add two other examples (Tariana and Menominee). The languages in question are diverse as regards language family and geography and the adjective "small" appears in four out of these six examples, while "big" is likewise found in four (with two languages having both); there is also one example of "other". I begin with the Modern Mainland Scandinavian languages (Danish, Norwegian, Swedish) from which we already saw an example in (1) above, repeated here as (7a) (see Ljunggren 1944 and Börjars \& Vincent 2011: 249-259). The adjectives in question are Swedish and Norwegian sg. liten /Danish sg. lille "small", pl. små..$^{10}$

\footnotetext{
${ }^{10}$ In Swedish there are additional singular forms litet and lilla used depending on the declension class of the noun and definiteness of the phrase; for an overview of the Swedish noun system, see Holmes \& Hinchliffe (2013: 16 ff.). The Norwegian system is more complicated for some dialects, with a further suppletive form vesle used in singular definite noun phrases; see Börjars \& Vincent (2011: 255) and below.
} 


\begin{tabular}{|c|c|c|c|}
\hline \multirow[t]{3}{*}{ a. } & \multicolumn{3}{|c|}{ Swedish } \\
\hline & en & liten flicka & \\
\hline & & small girl & \\
\hline & \multicolumn{3}{|c|}{ "a small girl" } \\
\hline & två & små & flickor \\
\hline & two & small.PL & girl.PL \\
\hline & "two & mall girls" & \\
\hline \multirow[t]{6}{*}{ b. } & \multicolumn{3}{|c|}{ Danish } \\
\hline & en & pige & \\
\hline & & small girl & \\
\hline & "a sn & lll girl” & \\
\hline & to & små & piger \\
\hline & two & small.PL & girl.PL \\
\hline
\end{tabular}

These adjectives go back to Old Norse litil "small" and smár "small" both of which had full paradigms for number, definiteness and case, as well as comparative and superlative forms. They are in part synonymous in this period. However, when used with singular count nouns, smár usually has the sense "composed of small parts", e.g. smár skógr [small forest.SG] "forest consisting of small trees"; cf. Modern Swedish, Norwegian småskog, Danish småskov, although native speakers consulted for each language said the word was relatively unfamiliar to them. Smár can also denote "insignificant, of little value" as well as "mean, mean-spirited, particular” (Börjars \& Vincent 2011: 250-251; Ljunggren 1944: 50-54).

Derivatives of smár become more restricted in their use with time in Danish, Norwegian and Swedish, and are eventually confined to use with plurals, and the modern paradigm illustrated in (7) is mostly in place by the eighteenth century. With singular count nouns, små remains productive in the sense "in small pieces" while the distributive or component size sense (e.g. "small gravel") also survives, albeit less productively (Börjars \& Vincent 2011: 255-256). Conversely, liten is no longer used in plural noun phrases in any of the Mainland Scandinavian languages. ${ }^{11}$ Furthermore, the superlative and comparative forms of smár (Old Norse smarre, smarrzt) fall out of use and are replaced by those of litil (Old Norse minni, minztr; Modern Mainland Scandinavian mindre, minst). The paradigm of lítil and its modern descendants is suppletive, but the Old Norse paradigms show that mindre and minst belong to the paradigm of liten/lille in the earlier period (Börjars \& Vincent 2011: 249 250). For små, only Swedish retains the comparative form smärre but this is not used for actual comparison but rather for the 'absolute comparative', translatable into English as "fairly X", "quite X" or "minor X", see Holmes \& Hinchliffe $(2013: 131,137)$ and Börjars \& Vincent (2011: 257).

The Australian Aboriginal language Mara (Northern Territory, Australia, see Heath 1981: 78 and Corbett 2007: 32) has number suppletion in three adjectives. It is notable that plural marking on these adjectives is used on non-human as well as human referents, while in

\footnotetext{
${ }^{11}$ Some Danish dialects still use the plural of liten, which can also be used in expressions of endearment, e.g. lille venner [small friend.PL] "dear little friends" (Börjars \& Vincent 2011: 257).
} 
other environments plural agreement is usually restricted to human referents. I return to this point below.
a. $\quad$ sg./dual ggiyu (usually non-human)/ggiyu-ña (usually human) "small”, pl. ṇiriri
b. sg./dual balwayi "big", pl. ganuganu
c. sg. gayi (nominative)/-argul (oblique) "other", pl. wayara

Megleno-Romanian (Daco-Romance) similarly has suppletion with "small" and "big". There is some variation between dialects and the forms given here are the most common ones; see Maiden (2014: 35-37) for more details. The bracketed forms given here are approximations of the IPA values as given by Maiden.
a. sg. [mik] (masc.), ['mikə] (fem.) “small”, pl. [mi'nuts] (masc.), [mi'nuti] (fem.)
b. sg. ['mari] (masc. and fem.) "big", pl. [mətf'kats] (masc.), [mət fkati] (fem.)

The regular plural [mar] of ['mari] "big" does also occur, albeit rarely, and there seems to be variation between dialects (Maiden 2014: 37). In terms of origin, [mik] lacks a known etymology in Latin and it has been suggested to be 'expressive' in origin (Maiden 2014: 38; Ciorănescu 1966: s.v. mic). The suppletive plurals [mi'nuts] and [mi'nuti] derive from Latin minütus, hence providing a close parallel to Breton and Cornish. This adjective is also attested in the singular form [mi'nut], and [mik] and [mi'nut] can therefore be said to stand in an asymmetrical relationship: the former lacks a plural while the latter has a full paradigm. We find a similar asymmetry with "big" in Tariana (see below). When used with singular count nouns, [mi'nut] denotes "composed of small pieces" (Maiden 2014: 39).

['mari] is usually taken as a derivative from Latin mas, accusative marem "male", probably through the development from "male" to "grown man" and, therefore, "big". The suppletive plural [mət 'kats] has a singular [mət 'kat]. Note again the asymmetry in the adjectives for "big"; [mət 'kat] has a full paradigm while ['mari] only has a singular form. Just as [mi'nut] can be used with count singulars to refer to component size, [mət/kat] can be used with singulars in the sense "composed of large parts". Maiden (2014: 40-41) gives an example where the speaker describes cutting leaves to feed silkworms, and how these could be chopped into increasingly larger pieces as the worms grew bigger. The origin of [mət $\left.{ }^{\prime} k a t\right]$ is somewhat complex. It derives originally from a Romance word meaning "club, mace, heavy stick". Its Romanian cognate măciucat has the primary meanings "(of a stick) having a rounded, enlarged end" and "knobbed". An "apparently related noun" măciulie denotes "the enlarged and rounded head of some objects" and also "dehiscent fruit with a dry, hard casing, in which the seeds of some plants develop and are kept; capsule". Romanian măciucat has further developed into măşcat which has the meanings "(of cereals) having a large seed [...] (of the seeds of cereals, of granules, etc.) that which is bulging, large, full". Maiden (2014: 37-40) suggests that the association with "large seeds, grains, capsules" of plants is what led to this word becoming a general adjective for "big". The development of Megleno-Romanian "big", then, does not directly parallel that of "small" since its original meaning is not something like "chopped into large parts". However, there is an element of component size in its semantics, as pointed out by Maiden (2014: 41, 45), since plants producing seeds and grains usually occur as a mass in a field and each individual plant within that mass can have large or small seeds, grains or capsules. This component size sense has been extended to other contexts as is clear from the example with chopped up leaves.

The fourth example comes from Menominee, an Algonquian language spoken in Wisconsin. Menominee does not have adjectives but it has particles used as prenouns and 
preverbs denoting qualities. The prenoun for "big" used to be suppletive between singular and plural (Bloomfield 1975: 109, 119). ${ }^{12}$
a. maec- "big, large"
b. mamāh- "big, large, old"

In the period when Bloomfield was collecting his data, "big" was still suppletive, with maecmodifying singulars and mamāh- used with plurals; consider the pair maec-enaeniw "big man" and mamāh-enaeniwak "big men" (Bloomfield 1962: 41). By now maec- has been generalised in all environments and mamāh- has fallen out of use (Monica Macaulay, pc.). Furthermore, the use of "big" as well as "small" as derivational elements in verb stems also reflects the suppletive distinction between singular and plural; consider maeqnekaen "he/she/it is big"/mamāhkekaenok "they (animate) are big" and nahaenesew "he/she/it is small"/papiasewak "they (animate) are small" (Bloomfield 1962: 41-42). These verb stems contain as their roots maeqN- "large (of single things)" and mamāhk- "large (of multiple things)", and nahaen- "small (of single things)" and $p \bar{e} w$ - "small (of multiple things)" (in papiasewak this root is reduplicated with $p a$ - and contracted from /pēw-aese/ to /pyāse/ <piase>). While this is not inflectional suppletion which is the focus of my discussion, it is nevertheless significant that these derivational elements show a singular/plural distinction with "big" and "small", and in this they partially parallel prenouns and preverbs.

The fifth example of number suppletion is the adjective for "big, wide, long" in Tariana, an Arawak language spoken in Brazil (see Aikhenvald 2003: 173 and Brown et al. 2003).
a. sg. hanu "big, wide, long", pl. male
b. compare sg. male "thick, heavy", pl. male

The singular form hanu "big, wide, long" lacks a plural and this is supplied by another adjective, male "thick, heavy", which can be used with both singular and plural nouns. Aikhenvald (2003: 173) notes that "one could say that the meanings 'big' and 'thick, heavy' are distinguished only in singular but not in plural. The form hanu-pe (big-PL) exists, but only in the meaning 'many". Brown et al. (2003) describe this as 'overlapping suppletion'; note that this is similar to "small" in Megleno-Romanian where [mi'nut] "small" has a singular and plural form, while also supplying the plural cell of [mik] "small".

As we have seen, in the Scandinavian, Brittonic and Megleno-Romanian examples the plural member of the suppletive pair can be used to modify singular count nouns which yields a component structure reading. In Tariana, the examples given by Aikhenvald suggest that there is no such limitation with male "thick, heavy"; it can be used to modify singular count nouns, e.g. "abiu fruit", with no obvious component structure. The suppletive pair for "big" in Tariana therefore stands out as different among the examples of adjectival number suppletion reviewed so far. In addition to size, both hanu "big, wide, long" and male "thick, heavy" can denote shape and dimension. One reviewer suggests tentatively that this could be key to explaining why suppletion arises; width and length are two-dimensional properties while thickness is three-dimensional. Perhaps plural entities are more commonly viewed as three-dimensional ('bundles') compared to singulars, and this allows for male "thick, heavy" to take over the plural cell. The exact semantics of suppletion in Tariana remain a topic for

\footnotetext{
${ }^{12}$ I am grateful to Monica Macaulay for drawing my attention to the Menominee data and for help with the examples.
} 
further research. Tariana does, however, provide a parallel to the other languages or groups discussed here in that "big" marks plural consistently in all environments. In Tariana, adjectival number agreement is not compulsory with inanimates, yet the singular hanu "big, wide, long" never occurs with plurals (Aikhenvald 2003: 73, 173-174).

Table 3 is a summary of the languages or language groups discussed in this section, showing the forms used to modify singulars and plurals. The final column indicates whether the plural pair of the lexeme can occur with count singulars in the meaning "composed of small parts", e.g. Swedish, Norwegian småskog/Danish småskov "forest consisting of small trees". For Mara, no information was available for usage with singular count nouns.

Table 3. Summary of languages or language groups with number suppletion in adjectives.

\begin{tabular}{|c|c|c|c|c|}
\hline Language/group & Lexeme & $\begin{array}{l}\text { Modifies } \\
\text { singular }\end{array}$ & $\begin{array}{c}\text { (Usually) modifies } \\
\text { plural }\end{array}$ & $\begin{array}{l}\text { Pl. form used } \\
\text { with sg. count } \\
\text { noun } \rightarrow \\
\text { component size }\end{array}$ \\
\hline $\begin{array}{l}\text { Middle Breton and } \\
\text { Middle Cornish }\end{array}$ & small & bihan/byhan & munut/munys & + \\
\hline $\begin{array}{l}\text { Mainland } \\
\text { Scandinavian }\end{array}$ & small & liten/lille & små & + \\
\hline \multirow[t]{3}{*}{ Mara } & small & $\begin{array}{l}\text { ygiyu/ygiyu- } \\
\tilde{n} a\end{array}$ & ṇiriri & $?$ \\
\hline & big & balwayi & ganuganu & $?$ \\
\hline & other & gayil-argul & wayara & $?$ \\
\hline \multirow[t]{2}{*}{ Megleno-Romanian } & small & {$[\mathrm{mik}] /[$ 'mikə] } & [mi'nuts]/[mi'nuti] & + \\
\hline & big & ['mari] & 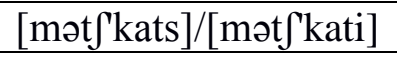 & + \\
\hline $\begin{array}{l}\text { Menominee (until } \\
\text { mid- to late } 20^{\text {th }} \mathrm{c} \text {.) }\end{array}$ & big & maec- & mamāh- & - \\
\hline Tariana & big & hanu & male & - \\
\hline
\end{tabular}

2.2 The development of number suppletion with "small" and "big"

It is striking that the typological picture in 2.1 is made up of the adjectives "small" and "big", with one example of "other". A generalisation can be made that, when number suppletion in adjectives occurs, this involves adjectives denoting size. The phenomenon itself is rare, but if new examples are uncovered, one would expect them to involve the lexemes for "big" or "small". As mentioned in the introduction, the most common adjectives with suppletion (usually in comparison) are "good" and "bad", followed by "big" and "small". Why, then, do we not find number suppletion with "good" and "bad"? The Scandinavian, MeglenoRomanian and Brittonic examples, where the history of the suppletive lexemes is known, suggest a pathway whereby adjectives denoting "chopped up small" or "composed of small parts" (= component size) can come to supply the plural cell of the paradigm of another adjective with a more general meaning "small". These adjectives are restricted in meaning and can only modify nouns with component structure (apart from some evaluative uses, on which see below). This usually involves nouns that are not singular and count, although some such nouns can also have component structure sensitive to size semantics (like the Welsh 
noun for "sieve" discussed in section 3). ${ }^{13}$ There is no such restriction to component structure within the different senses of "good" and "bad" which may explain why number suppletion never seems to occur with them.

That component structure can control the choice between two suppletive elements gains support from quantifiers. A well-known example is the distinction in English between many and much and few and little. Many and few are restricted to count plurals while much and little are used with non-count singulars. Such a distinction is not restricted to English but also found, for instance, in Mainland Scandinavian, e.g. Swedish många "many"/mycket "much" and lite "little"/fä "few" which largely parallel the English words given here as translations (see Holmes \& Hinchliffe 2013: 208-216). Finnish has a partially similar distinction; there are two words for "many, much", namely paljon and monta. The former can be used with both count and mass nouns, but monta is restricted to count nouns, e.g. monta naista [many woman.PARTITIVE.SG] "many women" (Karlsson 2015: 110; Karlsson's glossing of paljon only as "much" is somewhat misleading, since it can also be used for "many"). The distinction seen in quantifiers is not identical to that discussed above for suppletive adjectives, since "many, much" etc. are sensitive to mass and count, while we saw that suppletive paradigms for "big" and "small" often follow \pm component structure. This distinction does split mass and count, but it also splits mass further into aggregates and nonaggregates, with only the former modifiable by adjectives that can denote component structure. The lexeme "many, much" also commonly has suppletion in adjectival comparison, and there are some instances of suppletion for "few", see Bobaljik (2012: 124-126). Note that English much, like little, is in origin a size adjective, going back to an Indo-European lexeme for "big" (see Pokorny 1959: 708-709). It is notable that quantity and size adjectives are both prone to suppletion, especially in degree comparison but also in number.

As already noted, there is a close parallel between Breton and Cornish and MeglenoRomanian: the Megleno-Romanian plural forms [mi'nuts] and [mi'nuti] "small" derive from Latin minütus, the past participle of minuo (Maiden 2014: 39), like the Breton and Cornish suppletive plural forms munut and munys. Megleno-Romanian, then, is a very close parallel to Breton and Cornish in having a derivative of Latin minütus filling the plural cell of "small" while also having the sense "composed of small parts" when used with singular nouns. Looking at the meanings of Latin minuo in (4) above, the meanings "to become smaller" and "to make smaller" seem more prominent than "to cut/chop into small pieces", which Lewis and Short (1897) give as a "rare and mostly poetic" meaning, while DMLBS quotes only one example for this particular sense. The component size sense, which is primary in MeglenoRomanian and in Breton and Cornish, seems to have developed independently in these languages.

Why does the Welsh borrowing from minütus not pattern together with Breton and Cornish? The split from Brittonic into Old Welsh and South-West-British (later to develop into Breton and Cornish) is traditionally assumed to have commenced in the sixth century, although a more recent view puts it in the eight century, with mutual intelligibility lasting for possibly centuries after this (Schrijver 2011b: 4-7). Was minūtus borrowed separately into Old Welsh and South-West-British, or could it be an early borrowing into Common Brittonic,

\footnotetext{
${ }^{13}$ 'Component structure' is used throughout instead of the term 'internal structure', which is often used to explain the similarity between plurals ("books") and aggregate nouns ("sand") whose referents can be further divided yielding more of the same, see further Corbett (2000: 78-80) and Jackendoff (1991). This does not, however, work with the referent of e.g. "sieve"; dividing a sieve does not yield more sieves, yet the referent is perceived as having component structure (mesh with holes). 'Component structure' is used as a term that includes nouns of this type as well as plurals and aggregates.
} 
despite the later differences? Here it is useful to look at Welsh mynud, whose different meanings, as both a noun and an adjective, are listed in (3c) above. There is one uncertain Middle Welsh example where adjectival mynud could be interpreted as "shattered, broken" (and therefore perhaps "in small pieces") which would provide a parallel to its Breton and Cornish counterparts: $y$ iscuid oet mynud / erbin cath paluc "his shield was mynud against Cath Palug" (Black Book of Carmarthen, see Jarman 1982: 68, 11. 83-84, my translation). Mynud could here mean "smooth" in the sense that the shield had been worn smooth from fierce fighting with the supernatural creature Cath Palug, although "shattered" would also work in the context. However, since there are no other examples where "shattered" or "in pieces" is possible, we cannot put much weight on this example and the fact remains that W mynud does not match the semantics of the Breton and Cornish adjectives. One option is to assume that the meaning "composed of small parts" developed in South-West-British only. The lexeme could have existed in early Welsh with a different meaning which is later reflected in those in (3c), or it could have been borrowed into Welsh later. The latter is indirectly suggested by GPC stating that $\mathrm{W}$ mynud could be a borrowing from Latin via Old French, hence putting the borrowing much later than the Brittonic period. Another possibility is to consider $\mathrm{W}$ mynud as having developed like E minute (see 2.2 below) which originally denotes small size and possibly "chopped small" and develops an evaluative meaning ("very precise", etc.) with time. W mynud could have undergone a similar development from "small" to a meaning "courteous" and "courtesy", perhaps via a sense like "delicate" or "attentive to small detail", while losing the reference to size early.

There are many parallels to adjectives denoting small component size acquiring evaluative semantics, and vice versa, which demonstrate a possible semantic link between physical size and appreciation or contempt. English little, for instance, can denote either depending on context. Diachronically, it seems that an adjective can develop a size sense from an evaluative one, and vice versa. Consider, for instance, the history of $\mathrm{E}$ fine (all meanings and examples that follow are from $O E D$ online). A borrowing from French $f i n$ "thin, fine", its original meaning was A 1. "of superior quality, choice of its kind" (first attestation 1300). From this develops the sense A II "delicate, subtle" (with the sub-meaning A 6 a. "exquisitely fashioned; delicately beautiful", first attestation c. 1400). We then find the first hints of a developing size meaning under A 7 a. "delicate in structure or texture, delicately wrought; consisting of minute particles or slender threads or filaments." As noted in $O E D$, this sense often overlaps with A 1 . The first attestation of a component size meaning ("fine" as opposed to "coarse") is in 1535 (fyne floure). The meaning of fine fluctuates, therefore, between an evaluative sense ("of superior quality") and component-size ("consisting of minute particles").

The adjective minute shows a semantic broadening proceeding in the opposite direction. Its earliest attestation in 1440 (exact date uncertain) has the sense "chopped small"; this meaning becomes obsolete after this period. Meaning (3) is more productive: "very small in size, extent, amount, or degree. Also: (of distinction, etc.) fine, subtle". We find an evaluative meaning (4) "of very little consequence or importance; insignificant, petty, trivial" in 1668 but it becomes obsolete in the nineteenth century. While (4) shows a negative evaluative meaning, sense (5), which is still productive, is more positive: "of a person: exacting; discriminating. Of an observation, investigation, record, etc.: very precise or particular; characterized by attention to very small matters or details; painstaking". The semantic development of minute therefore broadens from denoting size to also marking evaluative distinctions.

As a final example, consider the development of nice; to list all the meanings given in $O E D$ would take too much space and I only give a short sketch of the main changes. A borrowing through the Anglo-Norman derivative from Latin nescius "unknowing, ignorant", 
the earliest meanings of E nice are evaluative and include "(of a person) foolish, silly, simple; ignorant", first attested c. 1300. Other negative evaluative meanings include "faint-hearted, timorous" and "slothful, sluggish"; these are attested in the fourteenth century. The sense "foolish" broadens to denote ostentatious dress, which in turn leads to "(of a person) finely dressed, elegant". Meanings given under (3) include some which are similar to minute above, such as "particular, strict, or careful with regard to a specific point or thing" and similar meanings are given under (7), including "minute, subtle; (of differences) slight, small". A good example of this is the phrase "a nice distinction", synonymous with "a fine distinction". The most common meaning in Modern English, "kind or considerate in behaviour; friendly (towards others)", is first attested in 1830. Such positive meanings can also be used ironically whereby the positive sense can be inverted. The history of nice, then, is one of fluctuation between negative and positive evaluative connotations, and notably it could also be used to denote "small" and "fine" in its earlier history.

It is clear from these examples that there is often a link between adjectives denoting "small" and evaluative semantics, including contempt (small= insignificant, trivial) and high regard or admiration (small= of fine quality, (of a person) exacting, precise). ${ }^{14}$ It should be noted that such diachronic semantic changes are unpredictable and cannot be used to formulate strong predictions (see Fortson 2003). Nevertheless, a consideration of the examples above provides a possible explanation for the difference between $\mathrm{W}$ mynud and its Breton and Cornish cognates. Mynud is attested as both a noun "courtesy, gentility, etc." and adjective "courteous, civil, etc." from the Middle Welsh period onwards. It is employed in descriptions of courteous and courtly behaviour, used of knights and noblemen, in medieval Welsh prose and poetry (see Phillips 2000: 357). Since it is a borrowing from L minūtus, W mynud could represent a stage where the reference to something having been made smaller has broadened to an evaluative sense, while the reference to size has disappeared. This development would be partially similar to that of E minute, itself a derivative of minutus, which also develops an evaluative sense, while simultaneously keeping its size reference unlike W mynud. I wonder, therefore, whether we could consider W mynud as originally being an adjective of size like its Breton and Cornish cognates, while this meaning was completely superseded by the new evaluative sense? This could have been aided by the existence of mân "small" which already fulfils the functions of an adjective used mostly with plurals. The exact chronology of these changes remains an open question and should be taken into consideration in discussing innovations in Breton and Cornish, or South-West-British, which differ from what we find in Welsh.

\subsection{Number suppletion in adjectives and inherent vs. contextual inflection}

The previous section looked at some semantic factors with the type of adjectives which can acquire number suppletion, namely adjectives denoting size. From the point of view of morphological theory, number suppletion in the category of adjectives is somewhat unexpected. The study of suppletion in a sample of thirty languages by Hippisley et al. (2004) demonstrates why suppletion is rarer with some grammatical categories than others. They propose three "conserving properties", at least one of which is displayed by each of the lexical items in the sample showing suppletion. These are (a) high frequency; (b) inherent inflection; and (c) suppletion being morphologically systematic (Hippisley et al. 2004: 392-

\footnotetext{
${ }^{14}$ That smallness and evaluation are semantically linked is also borne out by studies on the category of diminutives cross-linguistically, see Jurafsky (1996: esp. 547-551). He posits the meaning "child", and morphemes semantically and/or pragmatically associated with children, as the origin of the diminutive as a semantic category (pp. 562-564).
} 
407). Property (a), that suppleting lexemes tend to be high-frequency items, has been observed in many previous studies. Property (c) refers to "the distribution of phonologically distinct stems over the morphosyntactic cells within a paradigm" (p. 398). For instance, Latin regular verbs are traditionally taken as having three stems (present active indicative, perfect active and perfect past participle). When a verb has suppletive stems, they follow this threeway system. Property (b) is of most interest to the present discussion. Following Booij (1996), Hippisley et al. (2004: 395) distinguish contextual and inherent inflection. Adjectival agreement in number, gender and case falls under contextual inflection, in which "the presence and value of the category is dictated by the syntax, for example agreement markers on targets." Inherent inflection, on the other hand, refers to inflection which is not controlled by any other constituent, for example number marking on nouns or degree marking on adjectives. Hippisley et al. (2004: 396-398, 409-411) note that there are exceptions to property (b) including the Danish adjective for "small" discussed above, and that this is possible as long as the lexeme in question has at least one of the other two properties. "Small" in Danish has properties (a) and (c); the lexeme has high frequency and suppletion follows the regular pattern of number and definiteness marking. High frequency is likely to be true of all the languages discussed in 2.1 above since the lexical items involved, "big", "small" and "other", are salient.

A further typological observation arises from comparing the languages in 2.1, namely that many of the adjectives which have number suppletion also mark singular/plural oppositions more often than is common for the languages in question. Medieval Breton and Cornish have virtually lost number agreement with adjectives, yet with "small" we find consistent use of the plural form with plural nouns. Similarly, in Mara the singular form of the adjective is normally used with non-human referents (especially inanimates), but plural forms are used rigorously even with non-humans with the three adjectives which have suppletive plurals. This is also the case with "big" in Tariana, where agreement is otherwise only found with animates.

In Norwegian, number and definiteness combine to create an 'overdifferentiated' paradigm for "small" (Corbett 2007: 31-33). In addition to the liten/små distinction seen in 2.1, some Norwegian dialects have a further suppletive element vesle used in singular definite noun phrases while liten is restricted to indefinite phrases. As a further complication, the Bergen dialect uses små in singular definite phrases as well as in the plural (see Börjars \& Vincent 2011: 252-253). Normally adjectives in Norwegian have only three forms: singular indefinite masculine and feminine, singular indefinite neuter and one form for singular definite and plural (all genders). Liten has, depending on dialect, four to five forms and therefore it is said to be overdifferentiated. No other Norwegian adjectives have a different stem according to definiteness and hence Property (c) is not met, as noted by Börjars \& Vincent (2011: 261). In contrast, Breton and Cornish, Mara and Tariana already have singular and plural cells in the paradigm of adjectives, but using a plural form is optional. There appears to be a link between number suppletion and overdifferentiation or marking plural consistently in environments where it is otherwise optional or rare.

We have just seen two generalisations about number suppletion in adjectives. First, it appears to be a type of contextual inflection where suppletion is less commonly attested compared with inherent inflection. Secondly, when a language has number suppletion in adjectives, those adjectives mark plural number consistently. Here it is worth considering two parallels to both generalisations which come from suppletion in verbs. Hippisley et al. (2004: 412-414) note that the verb "to be" often breaks all three of their "conserving properties" and state that this is unsurprising given the extreme irregularity of this lexeme crosslinguistically. For example, "to be" often breaks property (b) by being suppletive in person; consider, for instance, English am/are/is. Cross-linguistically this also occurs with some other 
high frequency verbs such as "to go", see Veselinova (2006: 78-86). The other, more complex parallel comes from languages which have suppletion in verbs according to number, as opposed to the more usual types of suppletion in tense, aspect, mood or polarity (see Hippisley et al. 2004: 395). Consider examples (12) and (13) from Hiaki (Uto-Aztekan, see Bobaljik \& Harley (forthcoming)) with the suppletive verbs weye/kaate "go, walk" (intransitive) and $m e$ 'a/sua "kill" (transitive):

$$
\begin{aligned}
& \text { a. Aapo weye } \\
& \text { 3SG walk.SG } \\
& \text { "S/he is walking" }
\end{aligned}
$$
b. Vempo kate
3PL walk.PL
"They are walking"

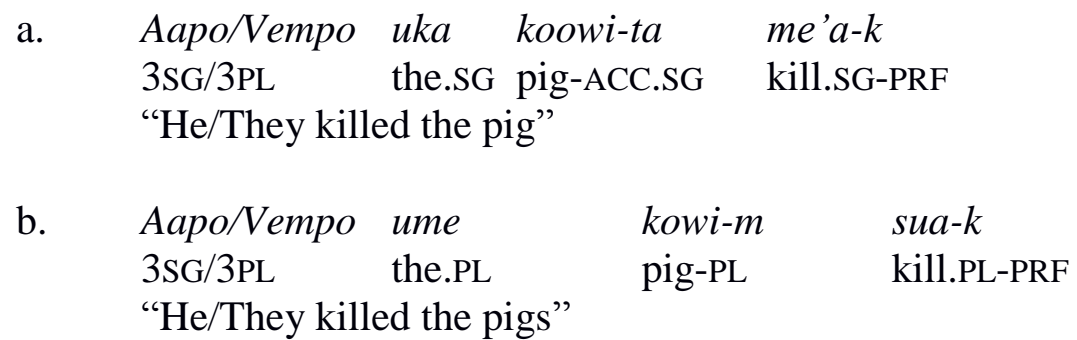

Bobaljik \& Harley (forthcoming) show that number-conditioned suppletion in Hiaki is governed by the internal argument of the verb according to an ergative-absolutive system. With intransitives verbal number reflects the number of the subject while with transitives it reflects that of the object, as seen in (13) where verbal number reflects the number of the direct object ("pig/pigs") rather than the subject. This suppletion pattern is attested in a number of other languages and treated as a type of verbal number, see especially Comrie (1982), Durie (1986) and Hale, Jeanne \& Pranka (1991). Corbett (2000: 243-264) and Veselinova (2006: 149-173) should be consulted for a detailed discussion of verbal number and various terminological and theoretical issues which are too numerous to outline here. Corbett distinguishes two types of verbal number: event number (how many times an action is performed, sometimes referred to as 'pluractionality') and participant number (number of participants most directly affected by the action). (12) and (13) are examples of suppletion according to participant number.

Whether this kind of suppletion should be considered a type of number agreement is debated. Durie (1986: 362) argues that in his examples "suppletive stems select for rather than agree with the number of their argument." This is shown by examples where regular syntactic agreement and suppletion behave differently. Hale, Jeanne \& Pranka (1991: 268) give an example of a suppletive verb in Navajo used in the comitative construction ("I am walking with the boy") where the verb stem used is dual reflecting the number of arguments, while the inflectional markers on the verb reflect the structural subject (first person singular). Such mismatches make it clear that suppletion is not part of regular plural inflection but rather a property of the verb itself. Similarly, Bobaljik \& Harley (forthcoming) argue that suppletive pairs in Hiaki do not reflect number agreement since, apart from those verbs that have suppletion, Hiaki does not have number agreement in verbs. Referring to Durie (1986) and Hale, Jeanne \& Pranka (1991), they argue that "participant-governed number suppletion is frequently independent of the agreement system of a language, and thus the numbergoverned alternations cannot be reduced straightforwardly to agreement." There are other languages, however, where suppletive verbal number pairs do seem to belong to the agreement system, so the question remains somewhat debatable (see Veselinova 2006: 158163). A crucial point for the present discussion is that adjectives, too, can be suppletive in number while the agreement system of the language does not otherwise mark agreement in 
adjectives or only marks it with animate referents. Of the languages discussed here, suppletion should be treated as separate from adjectival agreement in at least Breton and Cornish, Mara and Tariana since the suppletive adjectives do not follow regular patterns of syntactic agreement.

That suppletion in adjectives is not always simply a case of agreement could be supported by the use of 'plural' suppletive adjectives with singular nouns. In these instances the attributive adjective does not agree in number with the noun but rather reflects the component structure of the referent (e.g. a forest being a set of trees, gravel being a set of small stones, etc.). This is similar to some of the examples of verbal number where the verb selects for its arguments rather than agreeing with the number of the subject. While the similarities between number suppletion in adjectives and number suppletion in verbs require a more detailed treatment than is possible here, the parallel is significant. For both phenomena, we have examples where number suppletion is separate from syntactic agreement which is shown, for instance, by suppletive lexemes marking number differently from other lexemes, or marking number in environments where number is otherwise not marked. In verbs this is treated as a form of verbal number, and I leave open the question whether we could posit 'adjectival number' as a type of inherent inflection.

\subsection{Pre-conditions for suppletion}

Why do the kind of suppletive patterns seen in 2.1 occur cross-linguistically? This is explored by Börjars \& Vincent (2011: 240) who are concerned with pre-conditions for suppletion: how do suppletive patterns arise in a language? As already noted in the introduction, most studies on suppletion concentrate on explaining why it persists and resists levelling due to factors such as frequency, whereas the question of the genesis of suppletion has received less attention. Their analysis builds on Maiden's (2004) study of suppletion in Romance verb paradigms, e.g. French aller "go" the present tense forms of which reflect both Latin vadere "make one's way, rush" (e.g. je vais "I go") and ambulare "walk" (nous allons "we go"). Maiden argues that synonymy is a major force driving suppletion: in language acquisition, synonymy can arise either through language contact (children perceiving a native and an originally foreign lexeme as full synonyms) or through two lexemes having "largely coextensive" meanings the semantic difference of which may not be clear to all speakers (Maiden 2004: 248). A reaction to synonymy arising in one of these two ways is commonly for one of the synonyms to fall out of use. Börjars \& Vincent (2011: 242-243) argue that, while two elements do indeed need to be close in meaning for a suppletive paradigm to arise, there crucially needs to be "an asymmetry which is not well captured by the term "synonymy". The main argument of Börjars \& Vincent (2011: 245) is summarised in the following:

We will argue that this is a generalization about suppletion: it involves a semantically DOMINANT lexeme and a RECESSIVE lexeme and it is the former which becomes the receiving paradigm and the latter the donating one.

Furthermore, the dominant lexeme tends to be one with a more general meaning than the recessive one; we saw in 2.1 that this is the case, for example, with mainland Scandinavian liten/lille and små. I argue that this is also the case in Megleno-Romanian although this is

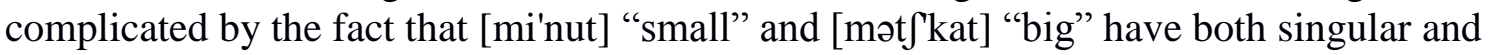
plural forms, while also providing suppletive plurals for [mik] and ['mari]. Despite having full paradigms, [mi'nut] and [mət 'kat] have less general meanings than [mik] and ['mari], since they derive historically from lexemes specifically denoting component size, and 
continue having this meaning when used with singulars. Crucially, only [mik] and ['mari] can be used with count singulars in the general meaning "small" and "big", showing that they are the dominant lexemes.

Maiden (2014: 45-48) defends the view that synonymy, not simply overlap, is at the root of suppletion in both the Megleno-Romanian and Scandinavian examples. He argues that the two lexemes forming a suppletive paradigm, such as [mik] and [mi'nuts] or liten and små, are indeed not fully synonymous when modifying singular nouns, since the distinction "X is small" and "X has small parts" is clear here. In the plural, however, such a distinction can be blurred; for instance, with två små flickor "two small girls" (see example (7) above) it is clear that each individual girl (each part of the plurality) is small and no other interpretation is available. In such cases we find what Maiden terms " "paradigmatically local' lexical synonymy" in the plural. ${ }^{15}$ In plural environments speakers could have perceived the old plural of, for example, liten as fully synonymous with små. It appears to me that this view is not incompatible with Börjars \& Vincent, since they look at the whole lexeme as opposed to treating singular and plural separately. If we look at the paradigms of liten and små as a whole, there is indeed partial overlap (mostly in the singular), but full synonymy can occur in the plural cell of the paradigm. This gains support from the Tariana data, discussed above, where the meanings "thick, heavy" and "big" are distinguished only in the singular by the use of different lexemes, while in the plural male "thick, heavy; big" is used for both meanings.

A key point of Börjars \& Vincent's analysis is that frequency only plays an indirect role in the genesis of a suppletive paradigm, that is, in cases where the dominant lexeme is also a frequent one. However, they argue the main cause to be the kind of semantic overlap described above. This accounts well with the data presented in 2.1; if frequency were the main factor, we would expect other frequent adjectives, especially "good" and "bad", to show number suppletion. For degree comparison, these are indeed the most commonly found lexemes. As for number suppletion, the prominence of "small" and "big" is striking and the analysis of the Scandinavian, Brittonic and Megleno-Romanian instances all support the finding that suppletion arises from two lexemes having partially overlapping meanings or, more specifically, meanings distinguishable in the singular but not necessarily in the plural.

In the following section I suggest that Welsh has a pair of lexemes for "small", one dominant and one recessive, which fulfil pre-conditions for suppletion, yet a fully suppletive paradigm of the Breton and Cornish type has not arisen.

\section{Welsh bychan, bach and mân "small"}

In the previous sections I discussed some features of adjectives that select for arguments with component structure, most commonly plurals, which can give rise to suppletion between singular and plural. It is significant that in all the cases where the history of the plural member of the suppletive pair for "small" is known, it seems to originate as a word expressing component size. These lexemes often lack comparative and superlative inflection, as is the case with Middle Breton, Middle Cornish and Mainland Scandinavian as discussed above. Welsh does not in any period of its history have number suppletion in adjectives as Breton and Cornish do. However, Welsh has two different adjectives for "small":

\footnotetext{
${ }^{15}$ It is possible to find a semantic distinction in the plural as well if a distributive meaning is available for the noun. Take, for example, words like sieve (the Welsh noun for which is discussed in the next section). Since a sieve has component parts (its mesh consists of holes which can be small or large), a phrase like "small sieves" could potentially be interpreted as each sieve having small holes (= being finely meshed), alongside the reading that each sieve that makes up the plurality is of small size (see Maiden 2014: 45). Even with this noun, however, the latter interpretation is more natural.
} 
bychan/bach is used with both singular and plural nouns while mân is mostly restricted to use with plurals, collectives and singular aggregates. This overlap in meaning resembles that found in Breton and Cornish, with the crucial difference that this partial overlap has not lead to the creation of a suppletive pair with bychan/bach in the singular and mân in the plural. Bychan and bach both denote "small, little", with no evident difference in meaning, and they are clearly etymologically related to one another.

$$
\begin{aligned}
& \text { bychan (masc.), bechan (fem.) "small”, pl. bychain } \\
& \text { bach "little, small", no feminine or plural forms }
\end{aligned}
$$

Both can modify singular as well as plural and collective forms; examples of the latter include Modern Welsh anifeiliaid bychan "small animals" (plural) and plant bach "small children" (morphological collective) (see CEG corpus for both). The comparative and superlative forms are llai "smaller" and lleiaf "smallest" which are suppletive and related to another adjective llaw "small" which is rare and falls out of use after the medieval period (GPC: s.v. llaw ${ }^{2}$, llai, lleiaf). The forms in (14) are usually analysed as bychan < Brittonic *bikko- +-an; the feminine bechan may go back to *bikka- +-an. The plural form bychain is likely to be an analogical formation in Welsh. The base forms *bych (masc.)/*bech (fem.) are cognate with Old Irish becc "small", compare also becán "a little, small quantity; a few, a small number; adv. a little, slightly; n. a little one" with the diminutive suffix -án (eDIL: s.vv. becc, becán). ${ }^{16}$ *Bych and *bech occur respectively in the place name Dinbych and the river name $D$ wyfech but are never found as attributive adjectives on their own. *Bych also seems to be the base of bychod "small quantity, little thing" and bychydig "little, few" (later ychydig) (GPC: s.v. bychod; bychydig; ychydig; see also Pedersen 1909: 385). In Middle Welsh bychan agrees with the number of the noun it modifies very regularly (Nurmio 2015: 167); for example, in the 13c corpus there are no examples of bychan with a plural noun. It could be argued that, since bychan had a full number paradigm in Middle Welsh, there was no need for suppletion to fill the plural cell. However, as already discussed in section 1.1, plural marking on adjectives is not compulsory in the medieval or modern Brittonic languages. The fact that Breton and Cornish have suppletion shows that lexemes with the kind of overlapping dominant/recessive relationship discussed above in section 2.4 can merge into a suppletive paradigm even when there is no need to fill one of the paradigm cells. Conversely, such an overlap does not have to lead to a merger of lexemes, as shown by the Welsh adjectives for "small".

The form bach "small" lacks Breton and Cornish equivalents. It is first attested in late Middle Welsh in the poetry of Dafydd ap Gwilym in the fourteenth century (GPC: s.v. bach). The etymology of bach is uncertain; it could be that *bych, discussed above, was interpreted as a plural form (on the model of vowel alternation plurals like alarch "swan", pl. elyrch with a high vowel in the plural) and bach arose as a back-formation. One could speculate whether sg. bach (and pl. *bych?) existed in the spoken language while bychan, pl. bychain were the forms in the literary register. Dafydd ap Gwilym's poetry has early or first attestations of other morphological forms; for example, he has one of the first instances of the singulative

${ }^{16}$ The relationship between Old Irish becán and the Brittonic forms is not straightforward. While the Irish suffix -án can be shown to go back to Celtic*-agn-, this cannot be the case for Brittonic where *-agn- would regularly result in /ain/, cf. MW Maen, OB Main, probably from L Magnus, see SimsWilliams 2003: 159-161 and Jackson 1953: 461. I agree with Jackson (1953: 461) and Sims-Williams (2003: 160) that the Welsh suffix -an is likely to be a borrowing from Old Irish personal names in -án and possibly some common nouns as well. 
suffix - $y n$ adding a person denotation in syml-yn "simpleton, fool" from the adjective syml "simple", and this part of the poem is presented as quoted speech, so it may indeed reflect a spoken usage hitherto unrepresented in the literary language (see Nurmio 2015: 83-84; 100). More research is required on this but it could be that forms which had existed in spoken Welsh earlier started to surface in writing in the poetry of this period. Bychan/bechan and bach remain difficult lexemes as regards their exact etymology, but in terms of usage, bychan is the basic form in Middle Welsh with bach appearing in texts in the fourteenth century. Both remain in use in Modern Welsh, although bach has taken over as the more common form; in the CEG corpus bach has 932 tokens against 379 for bychan/bechan/bychain.

We then have the adjective mân "small", which lacks cognates in Breton and Cornish and whose etymology is unknown. ${ }^{17}$ Mân has three main meanings as given in example (6) above which I repeat here as (16). All of these are attested from Middle Welsh onwards (there are no examples of mân in Old Welsh):

(16) mân (a) small, little (in size), (b) fine, thin, finely woven, not rough or coarse (of thread, \&c.); fine (of sieve or mesh); fine (of sand, salt, ashes, \&c.), ground small (of flour, \&c.); refined, elegant, (c) unimportant, trifling, insignificant; of inferior position, rank, \&c. (of person, also of court, \&c.); minor (of ailment), not very serious (of illness, fault, sin, \&c.)

It is found as an attributive adjective with the following noun types (based on all attestations in $G P C$ and the sample given in the Appendix): ${ }^{18}$

1. plurals: mân fryniau "small hills" (bryn "hill")

2. morphological collectives: mân adar "small birds"

3. aggregate nouns: blawd mân "fine flour"

4. abstract nouns: mân wallau "small errors" (gwall "error")

5. singular count nouns: mân llwdn "minor animal" (in a legal sense, see below)

Table 4 shows the number of occurrences of mân modifying nouns classified by the type of noun modified (singular, plural, collective or aggregate) in my sample which includes corpora of prose texts from the thirteenth century to present-day Welsh. This sample is given in the Appendix. In Table 4 each noun is only counted once for each group, i.e. the table shows types and not tokens.

Table 4. Types of nouns modified by mân "small" in the corpora.

\footnotetext{
${ }^{17}$ A full treatment of the etymological problems is beyond the scope of the present paper. My current working theory involves postulating a Proto-Celtic lexeme *menu- which could also be reflected in the Old Irish adjective min "small" and the Welsh verb difanw, difenwi "to belittle".

${ }^{18}$ As noted in 1.1, adjectives regularly follow the noun they modify in the Brittonic languages, but some adjectives can be placed before the noun. This triggers the soft mutation on the noun following the adjective, hence e.g. bryniau "hills" $\rightarrow$ mân fryniau "small hills" (see footnote 7 on the details of this mutation).
} 


\begin{tabular}{|l|l|l|l|l|l|}
\hline $\begin{array}{l}\text { corpora } \rightarrow \\
\text { noun modified } \downarrow\end{array}$ & \multicolumn{1}{|c|}{$\mathbf{1 3 c}$} & $\mathbf{1 3 0 0}-\mathbf{1 4 2 5}$ & $\mathbf{1 5 c}$ & $\mathbf{1 5 0 0}-\mathbf{1 8 5 0}$ & $\begin{array}{l}\text { ModW } \\
\text { [CEG] }\end{array}$ \\
\hline singular & 3 & 6 & 0 & 0 & 7 \\
\hline plural & 1 & 11 & 5 & 13 & 51 \\
\hline collective/aggregate & 2 & 14 & 4 & 4 & 10 \\
\hline
\end{tabular}

Mân is clearly an adjective mostly used with plural, collective and aggregate nouns and rare with singular count nouns. It is most commonly found with plurals overall (the 13c exception is discussed below), followed by collective and aggregate nouns. There are also instances with singular non-aggregate nouns, which fall into three categories: (i) the referent of the noun modified has component structure (e.g. a sieve) and mân modifies component-size rather than size of the object itself (e.g. a fine-meshed sieve); (ii) mân is employed as a compound element, forming specific technical terms, including legal and botanical terms; and (iii) mân is used pejoratively to denote insignificance or contempt. The sense in (iii) correlates with the position of mân before the noun, discussed below.

I begin by discussing examples of mân with singular count nouns in my sample. In the 13 c corpus these are mân llwdn "minor animal", anifail mân "minor animal" and gogr mân "fine-meshed sieve". With the last example, the sense is of a finely meshed sieve rather than a sieve of small size. The opposite gogr bras "coarse sieve" also exists, attested from the seventeenth century onwards (GPC: s.v. gogr; see below for discussion of bras "thick, coarse"). Mân llwdn and anifail mân both occur in the medieval Welsh law texts (see Appendix for the full references) where they are used in a technical sense of certain domestic animals of little value in terms of the compensation paid for their loss or for injury done to them. Peniarth 29 p. 94 specifies these as ay dauad ay gauar "either a sheep or a goat". In Cotton Titus D. ii, mân llwdn is used as the singular corresponding to the plurale tantum mân ysgrybl "small/minor livestock". ${ }^{19}$ Peniarth 29 p. 9 and BL Add. 14931, which have anifail mân as the singular, are different versions of the same law passage. Here mân ysgrybl are specified to be defaid "sheep", wyyn "lambs", mynnau "young goats", yrch "roe-deer" and elanedd "young deer". Other passages also mention pigs: hwch, pl. moch (on suppletion with this lexeme see Nurmio (forthcoming)). Mân ysgrybl, then, appears to mean specifically a certain group of domestic animals as well as deer, and mân llwdn and anifail mân are used when a singular is needed. An important generalisation from these examples is that mân can be employed in compounds for new, specific concepts such as the legal examples here. This usage remains productive, consider e.g. mân blanedau [small planets] "asteroids" and mân fwrdais [small bourgeois] "petit bourgeois" which are twentieth-century coinings.

Examples with singulars in the 1300-1425 corpus include cyngaf mân which is a specific botanical term for "fruit of agrimony", from cyngaf "burdock". Similarly, gwenynllys fân "Balm, Balm Gentle" is a specific term (from gwenynllys "Balm", cf. gwenynllys fawr "Bastard Balm, Melittis melissophyllum", a compound with mawr "big"). Both terms are found in medical texts (Meddyginiaethau). These botanical terms are best considered phrasal compounds rather than noun phrases with an attributive adjective (see Awbery 2014 and the discussion in 1.1 above). Gogr "sieve" and $l l w d n$ "animal" appear again in law manuscripts from this period. The remaining two examples are interesting in providing the first examples of the evaluative sense "unimportant". In the prose tale Manawydan we have yny oed ouer a man gueith holl grydyon y dref (White Book of Rhydderch version; the Red Book of Hergest

\footnotetext{
${ }^{19} \mathrm{Ysgrubl} / \mathrm{ysgrybl}$ is listed in GPC as having a singulative ysgrubl-yn but there are no attested examples in Middle Welsh and hence it is best treated as a plurale tantum in this period.
} 
has manweith as a compound) "until the work of all the shoemakers of the town was worthless (ofer) and insignificant (mân)" (my translation; see Appendix for references). ${ }^{20}$ The second example comes from another prose tale Culhwch ac Olwen: peth mor uan a'r rei hynn "something as insignificant (mân) as those ones". The singular nouns modified in these two examples are gwaith "work" and peth "thing" respectively.

It is clear, then, that if mân modifies singular nouns with no component structure, it has the meaning "unimportant; minor" or it is part of technical terms in legal and medical texts, as we saw with the other examples from this period. Crucially, mân cannot refer purely to size when used with singular nouns; bychan (and later bach) are used for that role. Examples from the Modern Welsh CEG corpus include crib mân "fine comb" and rhwyd fân "fine-meshed net" which are similar to gogr "sieve" above in that their referents have component structure. Print mân "fine print" and teip mân "fine type" may be calques on English fine print, or simply a reflection of treating printed text as a kind of aggregate consisting of component parts (letters) which can be small or large (see below for llythrennau "letters" which can be treated this way). Genau mân "small mouth" is more difficult but I wonder whether the writer thought of mouth being synonymous with lips (plural) which could have licensed the use mân. ${ }^{21}$ The final example is mân greadur "small creature" where it is not very clear why mân is used instead of bychan/bach; perhaps an evaluative sense "unimportant" is intended, although this is not obvious from the context.

Thomas (2006: 210) lists mân as one of a group of adjectives in Modern Welsh which have a different meaning depending on whether they precede or follow the noun they modify. The regular rule in Welsh is for adjectives to come after the noun, but a group of adjectives can vary their position, often with a change in meaning. Thomas gives as examples mân wendidau "minor weaknesses" (unimportant) vs. hadau mân "small seeds" (small in size). Other adjectives of this type include gwahanol which denotes "different" when placed after the noun and "various" when preceding it. The situation with mân is in fact not this simple. With non-human nouns, pre-posing mân often does not affect the semantics of the noun phrase; compare, for example, mân gerrig "small stones, pebbles" alongside cerrig mân with no perceptible difference in meaning (see the Appendix for the examples quoted here).

In my sample given in the Appendix, pre-posing is very common:

Table 5. Percentages of mân used before the noun modified.

\begin{tabular}{|l|l|l|l|l|l|}
\hline $\begin{array}{l}\text { corpora } \rightarrow \\
\text { mân } \text { pre-posed } \downarrow\end{array}$ & 13c & 1300-1425 & 15c & 1500-1850 & ModW [CEG] \\
\hline pre-posed tokens/total tokens & $11 / 13$ & $30 / 70$ & $7 / 9$ & $9 / 17$ & $42 / 98$ \\
\hline percentage of pre-posed & $85 \%$ & $43 \%$ & $78 \%$ & $53 \%$ & $43 \%$ \\
\hline
\end{tabular}

Mân is clearly very commonly used as an adjective before the noun. Middle Welsh provides many examples of pre-posing with aggregates, e.g. mân wlith "fine dew". The context does not suggest mân should be taken to mean "unimportant" here as opposed to "small".

\footnotetext{
${ }^{20}$ Manwaith could also reflect a usage similar to the English term "piecework", i.e. the other shoemakers were left with small jobs around the production of shoes, while the hero Manawydan actually made the shoes; this would still involve a degree of evaluation, since Manawydan clearly takes away the prestigious jobs from the other shoemakers, thus making them angry, as becomes obvious in the story.

${ }^{21}$ Genau "mouth" is in fact a plural form in origin as reflected in the ending -au (GPC: s.v. genau). Synchronically it is singular, however, with new plurals geneuau and geneuoedd, so this does not fully explain why the now-singular genau should occur with mân in Modern Welsh.
} 
Nevertheless, the sense "unimportant; minor" is already present in Middle Welsh as we saw with the singulars gwaith "work" and peth "thing" above. Jenkins (1986: 186) translates the phrase mân wŷdd/manwydd in the Welsh laws as "minor trees" since the sense here is not "trees of small size" but "trees that do not bear fruit" and therefore "less important trees" or "trees of less value". ${ }^{22}$ Mân anifeiliaid "small animals" is likewise a technical term in the laws for a certain group of animals, as discussed above. With abstract nouns, the sense tends to be "unimportant; minor" since these do not refer to physical size, e.g. MW mân bechodau "minor sins". The first examples of mân with a thuman noun come from the 1500-1850 corpus, and here pre-posing does correlate with the evaluative meaning: $y$ mân aerod a' $r$ crach foneddigion "the petty (mân) heirs and the contemptible nobles", and mân-ladron "petty thieves". In the Modern Welsh sample, all such evaluative examples with +human nouns have mân pre-posed (e.g. mân droseddwyr "petty criminals"). With non-human nouns, the evaluative meaning is sometimes clear, e.g. mân betheuach "unimportant things" with the plural suffix -ach which usually has a derogatory connotation (GPC: s.v. -ach). Other examples are ambiguous between "small" and "minor", e.g. mân newidiadau can be rendered into English as both "small changes" and "minor changes" and whether these are also "unimportant" depends on the context.

Mân can also form compounds with other adjectives, and these are listed separately in the Appendix. The earliest examples include manwyn "small or fine and white" (gwyn "white") and manfrith "finely speckled" (brith "speckled"), reflecting meanings (a) and (b) respectively of those listed in (16). I am aware of one possible example of the third and evaluative sense in an adjectival compound, namely penaetheu bychein anudonauc. / Meiri mangaled am pen keinhauc "petty, perjurous lords / stewards pettily strict (mân-galed) about a single penny" [my translation] (from the Middle Welsh poem 'Oianau Myrddin', Black Book of Carmarthen, see Jarman 1982: 30, 11. 46-47 and GPC: s.v. mân-galed, which is a compound with caled "hard, rough, strict"). Compounding is not common with bach and bychan. In this Welsh parallels the Scandinavian languages where små is often compounded with nouns, e.g. Old Swedish smabrödh "small bread" (in Modern Swedish also "biscuits"), while the liten-forms cannot form compounds (Börjars \& Vincent 2011: 251). The adverbial use of $\mathrm{W}$ mân further supports the finding that its basic reference is to component size rather than size of objects that cannot be divided further (adverbial uses are given separately in the Appendix). These examples include breaking, grinding and pounding things into smaller bits while the more basic sense "become small, make small (in size)" needs to be conveyed, for example, with lleihau "to become smaller or less" which is a derivative of the comparative llai "smaller" of bychan/bach (see above). It is clear from these examples that bychan/bach are the basic adjectives for "small", with mân being more restricted to describing component size.

Welsh has two adjectives for "big", again with partial semantic overlap, which share with the adjectives for "small" the potential to become suppletive, although such a shift has not taken place. The basic adjective is mawr "big" but we also find bras "thick, large" which partially parallels mân "small" in its semantics in having a reference to component size (as already noted by Fynes-Clinton 1913: s.v. ma:n). The range of meanings for bras include (GPC: s.v. bras):

\footnotetext{
${ }^{22}$ For the value of trees and trees in the Welsh laws in general, see Linnard (1979: esp. 6-9 for values of different species, and Linnard 2000: 42-49 for details of products derived from forests). For trees in the medieval Irish law, see Kelly (1997: 379-390). The focus in both the Welsh and Irish laws is on the usefulness of each tree, as sources of food for people or livestock, as building material etc., rather than on size.
} 
(17) (a) thick, fat, plump, stout, bulky, fatted, large, strong, also fig.; (b) coarse (of salt, sand, \&c.), heavy (of rain); (c) fatty, greasy, oily, viscid, also fig.; (d) fertile, abundant, plentiful; good, luxurious, sumptuous, rich, tasty; also fig.; (e) wealthy, affluent, prosperous; proud, confident, pompous, ostentatious; (f) rough (of material, the sea, \&c.); blunt, coarse, uncouth, vulgar, unseemly (of language, \&c.); harsh, strident, loud (of sound); (g) general, broad, approximate, rough.

Direct antonym pairs with mân include halen mân halen bras "fine/coarse salt",; llythrennau mân llythrennau bras (also llythrennau breision with the plural of bras) "small/large letters; lower-/upper-case letters" and the adverbial use in malu'n fân "to grind finely" malu'n fras "to grind roughly"; see Appendix for these examples with mân. Further examples are rhwyd fân "small-meshed net" and rhwyd fras "large meshed-net" and the collocation mân a bras "great and small" (GPC: s.v. mân; Fynes-Clinton 1913: s.v. ma:n). It is significant, however, that W bras does not have the meaning "large (as object size)". Its Breton and Cornish cognates (bras in both), on the other hand, do have this basic meaning. B meur (the cognate of $\mathrm{W}$ mawr), on the other hand, is more restricted and often has the evaluative meaning "great" (including "majestic" and "spectacular") and it is also common in place names. In addition to size, B bras can denote "major", "important", "serious". Roughly speaking the main difference between bras and meur is that the former can denote "large" and "stout (of a person)", while meur would imply that the person is great in importance (see Favereau 1992: s.vv. bras, meur and Hemon 1959-1979: s.vv. bras, meur). In Cornish the difference is not that clear and both bras and mür can have the basic size meaning "big" (Nance 1990: s.v. bras, mür).

We saw above that Megleno-Romanian and Mara have suppletion in the number paradigms of both "small" and "big", while Tariana has suppletion for "big" only. A detailed consideration of the semantics involved is beyond the scope of this paper, but it is clear that W bras should be considered alongside mân. These two adjectives can have the sense "composed of small/large parts" and other meanings to do with the component structure of referents, and they can also have evaluative meanings. While they overlap to some extent with the more basic adjectives bychan/bach "small" and mawr "big", their meanings are more specific. Finally, note that Breton and Cornish pattern together with "big" as well as "small" while Welsh differs from them.

A final point about mân as a component-size lexeme concerns its use in wordformation. There is a verbal derivative manu "to render small, divide, cut up into small pieces, reduce to powder, pound, also fig.; become small, crumble" (GPC: s.v. manaf: $\left.m a n u^{2}\right)$. Its attestations begin in the eighteenth century and it is not very common in use (the CEG corpus yields no hits), but a colloquial use is listed in GPC for Monmouthshire and Pembrokeshire where the examples involve crumbling coal and grinding salt. The verbal use of mân therefore reflects its use with referents with components that can be large or small, like coal. When mân forms close compounds, these also tend to denote aggregates, e.g. manar "tilth, fine earth" (GPC: s.v. manar") with $\hat{a} r$ "ploughed or arable land, tilth".

Breton munut and Cornish munys do not have comparative or superlative forms. In this they are like Mainland Scandinavian små which cannot be used in comparison either and this is further evidence of Börjars \& Vincent's argument that with suppletive lexemes like liten and små, the paradigm remains that of the dominant lexeme. W mân does have attested equative, comparative and superlative forms, but these are rare and again restricted to the

${ }^{23}$ The two are contrasted in the Middle Welsh text Rhinweddau Bwydydd: Dwy genedlaeth yssyd o'r halen. vn man ac un bras "there are two types of salt: one fine and one coarse" (Cardiff MS 3.242, p. 11 ; see the $1300-1425$ corpus). 
more specialised meanings "fine" and "unimportant; minor": the CEG corpus has one example each of the comparative (print manach "finer print") and superlative (po fanaf yr had, manaf y pridd "the finer the seed, the finer the soil"). There is one example that seems to refer to size, namely un manach "a smaller one (= person)" in a satirical late sixteenthcentury poem which can be treated as an exception since the final -ach is needed for rhyme. ${ }^{24}$ Finally the equative maned is listed in GPC in the meaning "as minor as".

Crucially, then, the derivatives as well as comparative and superlative forms of $\mathrm{W}$ mân reflect its more specific meanings "fine" (component size) and "unimportant; minor" (evaluative) and not the broader meaning "small (in size)". This is evidence that the dominant lexeme for "small" in Welsh is bach/bychan, with mân as a recessive lexeme which is sometimes near-synonymous with bach/bychan while also having more specific meanings.

\title{
4. Conclusion
}

This paper brought together previous studies on number suppletion in adjectives and highlighted a strong tendency for adjectives denoting size, "small" and "big", to develop this type of suppletion. Four languages or groups of closely related languages had so far been reported for this phenomenon, and I have added two languages to the discussion. Following Maiden (2014) the historical development of "small" becoming suppletive was argued to involve adjectives denoting component size ("chopped up small", "composed of small parts") taking up the plural cell of an adjective with a more general meaning "small". I reconsidered the views of Börjars \& Vincent (2011) and Maiden (2004, 2014) on the semantic factors which give rise to suppletive paradigms in adjectives, arguing that both semantic overlap and synonymy can be said to play a role. In languages where number agreement is optional, it was also observed that adjectives with number suppletion are likely to show plural agreement more rigorously than other adjectives and this was argued to be a parallel to what we find with suppletion and verbal number.

The case study in section 3 added Welsh to the discussion begun by Jørgensen (2012) on the adjectives for "small" in the Brittonic languages. I demonstrated that Welsh has adequate pre-conditions for suppletion: bychan/bach "small" have a general meaning "small" and can be used to modify both singular and plural nouns. Mân "small", on the other hand, has a more specific sense "composed of small parts" as well as "fine" (with aggregates) and the evaluative sense "unimportant; minor". This is a close parallel to the languages discussed in section 2 in which a suppletive pattern between singular and plural has arisen. However, this does not happen in Welsh, since both bychan/bach and mân occur regularly with plurals. This lends support to Börjars \& Vincent's observation (2011: 264) that knowing how suppletion can arise will not help us predict when it does or does not occur.

\author{
Abbreviations \\ B Breton \\ C Cornish \\ DMLBS Dictionary of Medieval Latin from British sources
}

\footnotetext{
${ }^{24}$ The manuscript reads Rys taylwr dysywr balch / Anoedd yw gweled vn manach (see Parry-Williams 1932: 252) where we should probably follow Parry-Williams in amending balch "proud" to bach "small" for rhyme, and hence "Rhys Taylor, the small dice-player / it's difficult to find one smaller [than him]". The comparative llai "smaller" of bach does not fit the rhyme here and manach may have been pushed to use to make the rhyme work, although it would not normally be used for "small (in size)".
} 


$\begin{array}{ll}\text { E } & \text { English } \\ \text { eDIL } & \text { Electronic Dictionary of the Irish Language } \\ \text { GPC } & \text { Geiriadur Prifysgol Cymru } \\ \text { L } & \text { Latin } \\ \text { MB } & \text { Middle Breton } \\ \text { MC } & \text { Middle Cornish } \\ \text { MW } & \text { Middle Welsh } \\ \text { W } & \text { Welsh }\end{array}$

\section{Bibliography}

\section{Corpora}

Brown, Dunstan, Marina Chumakina, Greville G. Corbett \& Andrew Hippisley (eds.), 2003. Surrey suppletion database. University of Surrey. http://www.smg.surrey.ac.uk/suppletion

Willis, David \& Ingo Mittendorf (eds.), 2004. Corpws hanesyddol yr iaith Gymraeg 1500 1850: A Historical corpus of the Welsh language 1500-1850. University of Cambridge. http://people.ds.cam.ac.uk/dwew2/hcwl/menu.htm. [1500-1850]

N. C. Ellis, C. O’Dochartaigh, W. Hicks, M. Morgan \& N. Laporte (eds.), 2001. Cronfa electroneg o Gymraeg (CEG): A 1 million word lexical database and frequency count for Welsh, Bangor University. www.bangor.ac.uk/canolfanbedwyr/ceg.php.en [CEG]

R. G. Roberts, S. Rowles \& P. Sims-Williams (eds.), 2015. Rhyddiaith y 15eg ganrif: Fersiwn 1.0, Aberystwyth University. http://hdl.handle.net/2160/26752 [15c]

G. R. Isaac, S. Rodway, S. Nurmio, K. Kapphahn \& P. Sims-Williams (eds.), 2013. Rhyddiaith Gymraeg o lawysgrifau'r 13eg ganrif: Fersiwn 2.0. Aberystwyth University. http://hdl.handle.net/2160/11163 [13c]

P. W. Thomas, D. M. Smith \& D. Luft (eds.), 2007-2013. Rhyddiaith Gymraeg 1300-1425: Welsh prose 1300-1425. Cardiff University. [1300-1425] http://www.rhyddiaithganoloesol.caerdydd.ac.uk [1300-1425].

\section{References}

Aikhenvald, Alexandra Y. 2003. A grammar of Tariana, from Northwest Amazonia. (Cambridge Grammatical Descriptions). Cambridge: Cambridge University Press.

Awbery, Gwenlliian. 2009. Welsh. In Martin Ball \& Nicole Müller (eds.), The Celtic languages, 359-426. London: Routledge.

Awbery, Gwenlliian. 2014. Problems with phrasal compounds in Welsh. Journal of Celtic Linguistics 15. 3-38.

Bauer, Bernhard. 2008. Studien zu den Altbretonischen Glossen. Vienna: Magister der Philosophie thesis. http://othes.univie.ac.at/685/. (4 March, 2016)

Bloomfield, Leonard. 1962. The Menomini language. New Haven and London: Yale University Press.

Bloomfield, Leonard. 1975. Menomini lexicon, ed. by Charles F. Hockett. Milwaukee Public Museum Publications in Anthropology and History 3.

Bobaljik, Jonathan David. 2012. Universals in comparative morphology: Suppletion, superlatives, and the structure of words. (Current Studies in Linguistics). Cambridge, MA: MIT Press.

Bobaljik, Jonathan David \& Heidi Harley. Forthcoming. Suppletion is local: Evidence from Hiaki. In Heather Newell, Maíre Noonan, Glynne Piggot \& Lisa Travis (eds.), The structure of words at the interfaces. Oxford: Oxford University Press. 
Booij, Geert. 1996. Inherent versus contextual inflection and the split morphology hypothesis. In Geert Booij \& Jaap van Marle (eds.), Yearbook of morphology 1995. 1-16. Dordrecht: Kluwer.

Börjars, Kersti \& Nigel Vincent. 2011. The pre-conditions for suppletion. In Alexandra Galani, Glyn Hicks \& George Tsoulas (eds.), Morphology and its interfaces. 239265. Amsterdam; Philadelphia: John Benjamins.

Ciorănescu, Alexandre. 1966. Diccionario etimológico rumano. La Laguna: Universidad de la Laguna.

Comrie, Bernard. 1982. Grammatical relations in Huichol. In Paul J. Hopper \& Sandra A. Thompson (eds.), Studies in transitivity. (Syntax and Semantics 15). 95-115. New York: Academic Press.

Corbett, Greville G. 2000. Number. (Cambridge Textbooks in Linguistics). Cambridge: Cambridge University Press.

Corbett, Greville G. 2007. Canonical typology, suppletion, and possible words. Language 83(1). 8-42.

Durie, Mark. 1986. The grammaticization of number as a verbal category. In Vassiliki Nikiforidou, Mary VanClay, Mary Niepokuj \& Deborah Feder (eds.), Proceedings of the twelfth annual meeting of the Berkeley Linguistics Society. 355-368. Berkeley, CA: Berkeley Linguistics Society.

Favereau, Francis. 1992. Dictionnaire du breton contemporain/Geriadur ar brezhoneg avremañ. Morlaix: Editions Skol Vreizh.

Fortson, Benjamin W. IV. 2003. An approach to semantic change. In Brian D. Joseph \& Richard D. Janda (eds.), The handbook of historical linguistics. 648-666. Oxford: Blackwell.

Fynes-Clinton, O. H. 1913. The Welsh vocabulary of the Bangor district. Oxford: Oxford University Press.

Hale, Kenneth, Laverne Masayesva Jeanne \& Paula M. Pranka. 1991. On suppletion, selection, and agreement. In Carol Georgopoulos \& Roberta Ishihara (eds.), Interdisciplinary approaches to language. 255-270. Dordrecht: Kluwer.

Heath, Jeffrey. 1981. Basic materials in Mara: Grammar, texts and dictionary. (Pacific Linguistics, vol. 60, Series C). Canberra: Australian National University.

Hemon, Roparz. 1975. A Historical Morphology and Syntax of Breton. Dublin: Dublin Institute for Advanced Studies.

Hemon, Roparz. 1959-1979. Geriadur istorel ar brezhoneg/Dictionnaire historique du breton. Rennes: Preder.

Hippisley, Andrew, Marina Chumakina, Greville G. Corbett \& Dunstan Brown. 2004. Suppletion: Frequency, categories and distribution of stems. Studies in Language 28(2). 387-418.

Holmes, Philip \& Ian Hinchliffe (eds.). 2013. Swedish: A comprehensive grammar. 3rd edn. New York: Routledge.

Jackendoff, Ray. 1991. Parts and boundaries. Cognition 41. 9-45.

Jackson, Kenneth. 1953. Language and history in early Britain. Edinburgh: Edinburgh University Press.

Jarman, A. O. H. (ed.). 1982. Llyfr Du Caerfyrddin. Cardiff: University of Wales Press. Jenkins, Daniel. (ed. and trans.). 1986. The law of Hywel Dda. Llandysul: Gomer.

Jørgensen, A. R. 2012. Plural Suppletion in Adjectives - the Case of the Plural of Breton and Cornish bihan "little". Paper presented at the workshop on Building Blocks of Breton Grammar, Philipps University of Marburg, April 26-27.

Jurafsky, Daniel. 1996. Universal tendencies in the semantics of the diminutive. Language 72(3). 533-78. 
Karlsson, Fred. 2015. Finnish: An essential grammar. 3rd edn. London: Routledge.

Kelly, Fergus. 1997. Early Irish farming: A study based mainly on the law-texts of the 7th and 8th centuries $A D$. (Early Irish Law Series 4). Dublin: Dublin Institute for Advanced Studies.

Latham, R. E., D. R. Howlett \& R. K. Ashdowne (eds.). 1975-2013. Dictionary of Medieval Latin from British sources. Oxford: British Academy. (DMLBS)

Lewis, Charlton T. \& Charles Short (eds.). 1897. A Latin dictionary founded on Andrews' edition of Freund's Latin dictionary. Oxford: Clarendon Press.

Lewis, Henry \& J. R. F. Piette. 1966. Llawlyfr Llydaweg Canol (diwygiedig). 3rd edn. Cardiff: University of Wales Press.

Linnard, William. 1979. Trees in the law of Hywel. (Pamphlets on Welsh Law). Aberystwyth: Centre for Advanced Welsh and Celtic Studies.

Linnard, William, 2000. Welsh woods and forests: A history. Llandysul: Gomer.

Ljunggren, Karl Gustav. 1944. Adjektiven liten och små. Arkiv för Nordisk Filologi 58. 4761.

Maiden, Martin. 2004. When lexemes become allomorphs - On the genesis of suppletion. Folia Linguistica 38(3-4). 227-256.

Maiden, Martin. 2014. Two suppletive adjectives in Megleno-Romanian. Revue Romane 49(1). 32-51.

Mel'čuk, Igor A. 1976. On Suppletion. Linguistics 170. 45-90.

Mel'čuk, Igor A. 1994. Suppletion: Toward a logical analysis of the concept. Studies in Language 18. 339-410.

Nance, R. Morton. 1990. Gerlyver noweth Kernewek-Sawsnek ha Sawsnek-Kernewek. Redruth: Dyllansow Truran.

Norris, Edwin (ed. and trans.). 1859. The ancient Cornish drama. vol. 1. Oxford: Oxford University Press.

Nurmio, Silva. 2015. Studies in grammatical number in Old and Middle Welsh. Cambridge: University of Cambridge $\mathrm{PhD}$ thesis.

Nurmio, Silva \& David Willis. 2016. The rise and fall of a minor category: The Welsh numerative. Journal of Historical Linguistics 6(2).

Nurmio, Silva. Forthcoming. Collective nouns in Welsh: a noun category or a plural allomorph? Transactions of the Philological Society 115.

OED Online. Oxford: Oxford University Press. www.oed.com (4 March, 2016).

Padel, Oliver. 1979-1980. Miscellania Cornica. Studia Celtica 14-15. 233-245.

Parry-Williams, T. H. 1932 (ed.). Canu rhydd cynnar. Cardiff: University of Wales Press.

Pedersen, Holger. 1909. Vergleichende Grammatik der keltischen Sprachen, vol. 1. Göttingen: Vandenhoeck und Ruprecht.

Phillips, Manon. 2000. Defod a moes y llys. In T. M. Charles-Edwards, Morfydd E. Owen \& Paul Russell (eds.), The Welsh king and his court. 347-361. Cardiff: University of Wales Press.

Pokorny, Julius 1959. Indogermanisches etymologisches Wörterbuch, vol. 1. Bern: Francke.

Schrijver, Peter. 2011a. Middle and Early Modern Breton. In Elmar Ternes (ed.), Brythonic Celtic-Britannisches Keltisch: From medieval British to Modern Breton. 359-429. Bremen: Hempen Verlag.

Schrijver, Peter. 2011b. Old British. In Elmar Ternes (ed.), Brythonic Celtic-Britannisches Keltisch: From medieval British to Modern Breton. 1-84. Bremen: Hempen Verlag.

Schumacher, Stefan. 2011. Mittel- und Frühneukymrisch. In Elmar Ternes (ed.), Brythonic Celtic-Britannisches Keltisch: From medieval British to Modern Breton. 85-235. Bremen: Hempen Verlag. 
Sihler, Andrew L. 1995. New comparative grammar of Greek and Latin. Oxford: Oxford University Press.

Sims-Williams, Patrick. 2003. The Celtic inscriptions of Britain: Phonology and chronology, c. 400-1200. (Publications of the Philological Society 37). Oxford: Blackwell.

Ternes, Elmar. 2011. Neubretonisch. In Elmar Ternes (ed.), Brythonic Celtic-Britannisches Keltisch: From medieval British to Modern Breton. 431-529. Bremen: Hempen Verlag.

Thomas, Alan R. 2000. The Welsh dialect survey. Cardiff: University of Wales Press.

Thomas, Peter Wynn. 2006. Gramadeg y Gymraeg. 3rd edn. Cardiff: University of Wales Press.

Thomas, R. J. et al. (eds.), 1950-. Geiriadur Prifysgol Cymru. Cardiff: University of Wales Press (2nd edition from 2003-, ed. Gareth A. Bevan \& P. J. Donovan et al., www.geiriadur.ac.uk [4 March, 2016]).

Toner, Gregory, et al. (eds.) 2013. Electronic dictionary of the Irish language. www.dil.ie. (4 March, 2016). (eDIL)

Veselinova, Ljuba N. 2006. Suppletion in verb paradigms: Bits and pieces of the puzzle (Typological Studies in Language 67). Amsterdam/Philadelphia: John Benjamins.

Watkins, T. Arwyn. 1961. Ieithyddiaeth: Agweddau ar astudio iaith. Cardiff: University of Wales Press.

Williams, N. J. A. 2011. Middle and Late Cornish. In Elmar Ternes (ed.), Brythonic CelticBritannisches Keltisch: From medieval British to Modern Breton. 237-357. Bremen: Hempen Verlag.

Willis, David. 2009. Old and Middle Welsh. In Martin J. Ball \& Nicole Müller (eds.), The Celtic Languages. 117-160. London: Routledge.

Willis, David. 2014. Maintaining the historical directionality of syntactic change in numeral phrases. Paper presented at the 16th Diachronic Generative Syntax Conference, Research Institute for Linguistics, Hungarian Academy of Sciences, Budapest, July 35 .

\section{Résumé}

Cet article étudie le phénomène typologique rare de la supplétion pour le nombre chez les adjectifs. On démontre comment cette supplétion se produit à partir de six exemples recensés, avec une attention particulière pour les langues brittoniques (breton, cornique et gallois). On propose trois généralisations sur la base de cette étude typologique. (i) Les adjectifs signifiant la taille («petit» et «grand») sont au cœur du phénomène. (ii) Lorsque l'étymologie des adjectifs est connue, la forme plurielle de la paire supplétive pour «petit» provient d'un lexème désignant quelque chose ayant été divisé en petites parties ou se composant de petites parties. Ces lexèmes peuvent également être utilisés pour modifier certains noms singuliers, auquel cas ils renvoient à la structure des éléments internes au référent. (iii) Les adjectifs avec supplétion pour le nombre tendent à marquer le pluriel systématiquement dans des contextes où le marquage au pluriel est sinon facultatif ou rare.

\section{Zusammenfassung}

Der folgende Artikel untersucht das typologisch ungewöhnliche Phänomen der Suppletion nach Numerus bei Adjektiven. Anhand von sechs bekannten Beispielen wird, mit speziellem Fokus auf die britannisch-keltischen Sprachen (Bretonisch, Kornisch und Walisisch), die Entstehung dieser Suppletion erklärt. Auf dieser typologischen Grundlage aufbauend, werden 
drei Prämissen angenommen: (i) Adjektive die Größe (,klein“ und „groß“) bezeichnen stehen im Mittelpunkt dieses Phänomens. (ii) Bei durchsichtiger Etymologie von Adjektiven entsteht die Pluralform von „klein“ aus einem Lexem, das etwas in kleine Teile Aufgeteiltes oder aus ihnen Bestehendes bezeichnet. Diese Lexeme können auch mit einigen Singularformen verwendet werden, wobei sie hierbei auf die Komponentenstruktur des Denotats verweisen. (iii) Adjektive bei denen Suppletion nach Numerus auftritt weisen auch in grammatikalischen Kontexten in denen der Plural ansonsten nur optional oder selten verwendet wird, regelmäßig Pluralflexion auf.

Author's address

Silva Nurmio

Dublin Institute for Advanced Studies

10 Burlington Road

Dublin 6

Ireland

silva@celt.dias.ie 


\section{APPENDIX: W MÂN "SMALL" IN THE CORPORA}

For the thirteenth century examples of the context for mân are given along with the manuscript references. In cases of multiple manuscript attestations, the citation is from the first listed manuscript and this may not be identical in orthography to the others. For the later corpora only references are given to save space and because readers can easily check the full readings in the online corpora. The 1300-1425 sample is given as a table due to the high number of references. I have provided English translations for all tokens and sometimes more than one translation is possible (between "small" or "minor", and "minor" or "unimportant", for example); I have picked a likely option in each case but this does not exclude other interpretations.

\section{PLURAL}

\section{THIRTEENTH CENTURY [13c]}

mân ysgrubl "small/minor livestock" (in the medieval Welsh laws, see discussion in section 3)

En e ky6reyth e b6 hwch or moch ne6 6n or man escrybyl re dywedassam ny wuchot (Cotton Caligula A.iii ff. 195v col. 2; Cotton Titus D.ii ff. 59v; Peniarth 29 p. 89)

Pwy bynnac a kaffo man escrybyl ay da6at. ay ga6yr. ay hwch. dewysset e deylyat. (Cotton Caligula A.iii ff. 198r col. 1; Cotton Titus D.ii ff. 61v)

E koc ar dysteyn pyeu cruyn e man escrybyl. Sef eu e rey heny. deueyt ar huyn ar meneu ar yrch ar alanet (Peniarth 29 p. 9; BL Add. 14931 p. 6; Cotton Titus D.ii ff. 4r)

ef a dely cruyn e man escrybyl oll or a del yr kekyn ac e uruyn amdanadunt (Peniarth 29 p. 19; Cotton Titus D.ii ff. 9r; BL Add. 14931 p. 15)

\section{mân anifeiliaid "small/minor animals" (in the laws)}

ac ny chefyr or man anyueyllyeyt gwyllt namyn hynny (BL Add. 14931 p. 84; Peniarth 29 p. 73)

a dyly trayan or trayan a el er brennyn o cruyn e man anyueylleyt guyllt (Peniarth 30 col. 216)

\section{SINGULAR}

mân llwdn "minor animal" (in the laws)

puy bennac a kafo man lludyn ar hyd ay dauad ay gauar (Peniarth 29 p. 94)

E dysteyn ar koc byeu krvyn e man escrebyl sef y6 y rey henny e deueyt ar vyn ar mynneu ar yrch. ar alaned a phob man llvdyn y del e kroen er kegyn amdana6 hyt en oet e llassven leyhaf (Cotton Titus D.ii ff. 4r)

anifail mân "minor animal” (in the laws)

ar a pop anyueyl man a del y croen yr kecyn amdanau (Peniarth 29 p. 9; BL Add. 14931 p. 6)

\section{MOPRHOLOGICAL COLLECTIVE}

mân wŷdd/manwydd "minor trees, trees of small value" (in the laws)

eythyr askelleyt ny byd henlleu hyd kalan mey kany guys ena a uyd byhu pop keycg or man guyt (Peniarth 29 p. 74; BL Add. 14931 p. 85:)

Pob pren keygya6c or manwyd. i. keynnya6c. ew y werth (Cotton Caligula A.iii ff. 190v col. 1)

Pob keync a gyrcho kallon e pren or manwyd ry dywedassam ny uchot (Cotton Titus D.ii ff. 54v)

\section{SINGULAR, +COMPONENT STRUCTURE}

gogr mân "fine sieve"

y g6r a dyly y rydyll ar wreic y gogyr man (BL Add. 14931 p. 24; Peniarth 29 p. 33; Cotton Titus D.ii ff. 14v)

\section{PLURAL}

FOURTEENTH CENTURY AND EARLY FIFTEENTH CENTURY [1300-1425]

\begin{tabular}{|l|l|l|}
\hline \multicolumn{1}{|c|}{ Example } & \multicolumn{1}{|c|}{ Text } & \multicolumn{1}{c|}{ Manuscript } \\
\hline $\begin{array}{l}\text { mân adafedd "fine } \\
\text { threads" }\end{array}$ & Ymborth yr Enaid & NLW MS. Llanstephan 27 (Llyfr Coch Talgarth), p. 37r; \\
& & NLW MS. Peniarth 15, p. 46; NLW MS. Peniarth 15, p. 49; \\
& & NLW MS. Peniarth 190, p. 199; NLW MS. Peniarth 190, p. \\
& & 208; Oxford, Jesus College MS. 119 (Llyfr Ancr Llanddewi \\
& & Brefi), p. 83v; Oxford, Jesus College MS. 119 (Llyfr Ancr \\
& & Llanddewi Brefi), p. 86v; Oxford, Jesus College MS. 20, p. \\
\hline
\end{tabular}




\begin{tabular}{|c|c|c|}
\hline & & 22r; Oxford, Jesus College MS. 20, p. 27r \\
\hline $\begin{array}{l}\text { mân anifeiliaid } \\
\text { "small/minor } \\
\text { animals (in the } \\
\text { laws)" }\end{array}$ & Llyfr Iorwerth & NLW MS. Peniarth 32 (Y Llyfr Teg), p. 141 \\
\hline $\begin{array}{l}\text { camau bychain mân } \\
\text { "small, careful (?) } \\
\text { steps" }\end{array}$ & $\begin{array}{l}\text { Llythyr Aristotlys at } \\
\text { Alecsander: Pryd a } \\
\text { Gwedd Dynion }\end{array}$ & Cardiff MS. 3.242 (Hafod 16), p. 18 \\
\hline $\begin{array}{l}\text { mân gasnod "fine } \\
\text { threads" }\end{array}$ & Ymborth yr Enaid & $\begin{array}{l}\text { NLW MS. Llanstephan } 27 \text { (Llyfr Coch Talgarth), p. 34v; } \\
\text { NLW MS. Peniarth 15, p. 46; NLW MS. Peniarth 190, p. 199; } \\
\text { Oxford, Jesus College MS. 20, p. 22r }\end{array}$ \\
\hline $\begin{array}{l}\text { mân ddafnau "small } \\
\text { drops" }\end{array}$ & Ymborth yr Enaid & $\begin{array}{l}\text { NLW MS. Llanstephan } 27 \text { (Llyfr Coch Talgarth), p. 35r; NLW } \\
\text { MS. Peniarth 190, p. 200; Oxford, Jesus College MS. } 119 \\
\text { (Llyfr Ancr Llanddewi Brefi), p. 84r; Oxford, Jesus College } \\
\text { MS. 20, p. 22v }\end{array}$ \\
\hline $\begin{array}{l}\text { mân ddagrau "small } \\
\text { tears" }\end{array}$ & Ymborth yr Enaid & $\begin{array}{l}\text { NLW MS. Llanstephan } 27 \text { (Llyfr Coch Talgarth), p. 35r; NLW } \\
\text { MS. Llanstephan } 27 \text { (Llyfr Coch Talgarth), p. 37v; NLW MS. } \\
\text { Llanstephan } 27 \text { (Llyfr Coch Talgarth), p. 39r; NLW MS. } \\
\text { Peniarth 15, p. 46; NLW MS. Peniarth 15, p. 46; NLW MS. } \\
\text { Peniarth 15, p. 49; NLW MS. Peniarth 15, p. 51; NLW MS. } \\
\text { Peniarth 190, p. 200; NLW MS. Peniarth 190, p. 210; NLW } \\
\text { MS. Peniarth 190, p. 215; Oxford, Jesus College MS. } 119 \\
\text { (Llyfr Ancr Llanddewi Brefi), p. 84r; Oxford, Jesus College } \\
\text { MS. } 119 \text { (Llyfr Ancr Llanddewi Brefi), p. 87v; Oxford, Jesus } \\
\text { College MS. 119 (Llyfr Ancr Llanddewi Brefi), p. 89r; } \\
\text { Oxford, Jesus College MS. 20, p. 22v; Oxford, Jesus College } \\
\text { MS. 20, p. 28r }\end{array}$ \\
\hline $\begin{array}{l}\text { difynion mân "small } \\
\text { pieces" }\end{array}$ & Ystoriau Saint Greal & NLW MS. Peniarth 11, p. 151r \\
\hline $\begin{array}{l}\text { mânddodrefn } \\
\text { "small furniture" }\end{array}$ & Llyfr Cyfnerth & NLW MS. Peniarth 37, p. 33v \\
\hline \multirow[t]{4}{*}{$\begin{array}{l}\text { dryll(i)au mân, mân } \\
\text { ddryll(i)au "small } \\
\text { (broken) pieces, } \\
\text { fragments" }\end{array}$} & Brut y Brenhinedd & $\begin{array}{l}\text { BL MS. Cotton Cleopatra B V part i, p. 21v; BL MS. Cotton } \\
\text { Cleopatra B V part i, p. 6v; BL MS. Cotton Cleopatra B V part } \\
\text { i, p. 70v; BL MS. Cotton Cleopatra B V part i, p. 93r; NLW } \\
\text { MS. 3035 (Mostyn 116), p. 126v; NLW MS. 3035 (Mostyn } \\
\text { 116), p. 92r; NLW MS. Peniarth 19, p. 68r; NLW MS. } \\
\text { Peniarth 19, p. 86r; NLW MS. Peniarth 21, p. 11r; Cardiff MS. } \\
\text { 1.362 (Hafod 1), p. 63v; Cardiff MS. 1.362 (Hafod 1), p. 93r; } \\
\text { MS. Philadelphia 8680, p. 51v; Oxford, Jesus College MS. } \\
111 \text { (Llyfr Coch Hergest), p. 34r; Oxford, Jesus College MS. } \\
111 \text { (Llyfr Coch Hergest), p. 50r }\end{array}$ \\
\hline & Brut y Saeson & Oxford, Jesus College MS. 111 (Llyfr Coch Hergest), p. 249v \\
\hline & $\begin{array}{l}\text { Saith Doethion } \\
\text { Rhufain }\end{array}$ & $\begin{array}{l}\text { Oxford, Jesus College MS. } 111 \text { (Llyfr Coch Hergest), p. 128v; } \\
\text { Oxford, Jesus College MS. } 111 \text { (Llyfr Coch Hergest), p. 128v; } \\
\text { Oxford, Jesus College MS. 20, p. 45v; Oxford, Jesus College } \\
\text { MS. 20, p. 46r }\end{array}$ \\
\hline & $\begin{array}{l}\text { Ystoria Carolo } \\
\text { Magno: Can Rolant }\end{array}$ & $\begin{array}{l}\text { NLW MS. Peniarth 10, p. 45v; NLW MS. Peniarth 7, p. 40r; } \\
\text { NLW MS. Peniarth } 8 \text { part i, p. 62; NLW MS. Peniarth } 8 \text { part } \\
\text { ii, p. 32; Oxford, Jesus College MS. } 111 \text { (Llyfr Coch Hergest), } \\
\text { p. 114v; Oxford, Jesus College MS. } 111 \text { (Llyfr Coch Hergest), } \\
\text { p. 115r }\end{array}$ \\
\hline $\begin{array}{l}\text { mân weison "small } \\
\text { boys" }\end{array}$ & Diarhebion & Oxford, Jesus College MS. 111 (Llyfr Coch Hergest), p. 239r \\
\hline
\end{tabular}




\begin{tabular}{|l|l|l|}
\hline $\begin{array}{l}\text { gwenynllys fân } \\
\text { "balm, balm gentle" }\end{array}$ & Meddyginiaethau & $\begin{array}{l}\text { Oxford, Jesus College MS. 111 (Llyfr Coch Hergest), p. 231v; } \\
\text { Oxford, Jesus College MS. 111 (Llyfr Coch Hergest), p. 232r }\end{array}$ \\
\hline $\begin{array}{l}\text { mân bechodau } \\
\text { "minor sins" }\end{array}$ & $\begin{array}{l}\text { Rhinweddau Gwrando } \\
\text { Offeren }\end{array}$ & $\begin{array}{l}\text { NLW MS. Llanstephan 27 (Llyfr Coch Talgarth), p. 56r; NLW } \\
\text { MS. Peniarth 32 (Y Llyfr Teg), p. 273 }\end{array}$ \\
\hline $\begin{array}{l}\text { mân bethau "small } \\
\text { things" }\end{array}$ & Llyfr Iorwerth & NLW MS. Peniarth 32 (Y Llyfr Teg), p. 31 \\
\hline $\begin{array}{l}\text { toriadau mân "small } \\
\text { cuts" (as decoration) }\end{array}$ & $\begin{array}{l}\text { Ystoria Carolo } \\
\text { Magno: Rhamant } \\
\text { Otfel }\end{array}$ & Oxford, Jesus College MS. 111 (Llyfr Coch Hergest), p. 106v \\
\hline
\end{tabular}

\section{COLLECTIVE/SINGULAR, + COMPONENT STRUCTURE}

\begin{tabular}{|c|c|c|}
\hline Example & Text & Manuscript \\
\hline mân adar "small birds" & $\begin{array}{l}\text { Ystoria Bown de } \\
\text { Hamtwn }\end{array}$ & Oxford, Jesus College MS. 111 (Llyfr Coch Hergest), p. 216v \\
\hline \multirow[t]{2}{*}{ blawd mân "fine flour" } & Campau'r Cennin & Oxford, Jesus College MS. 111 (Llyfr Coch Hergest), p. 235v \\
\hline & Meddyginiaethau & $\begin{array}{l}\text { BL Additional MS. 14,912, p. 41r; BL Additional MS. 14,912, } \\
\text { p. 41v; BL Additional MS. 14,912, p. 43r; BL Additional MS. } \\
\text { 14,912, p. 44v; BL Additional MS. 14,912, p. 69v; Cardiff MS. } \\
\text { 3.242 (Hafod 16), p. 84; Cardiff MS. 3.242 (Hafod 16), p. 85; } \\
\text { Cardiff MS. 3.242 (Hafod 16), p. 85; Cardiff MS. 3.242 (Hafod } \\
\text { 16), p. 86; Oxford, Jesus College MS. } 111 \text { (Llyfr Coch } \\
\text { Hergest), p. 232v; Oxford, MS. Rawlinson B 467, p. 24r; } \\
\text { Oxford, MS. Rawlinson B 467, p. 31v; Oxford, MS. Rawlinson } \\
\text { B 467, p. 48v; Oxford, MS. Rawlinson B 467, p. 50r; Oxford, } \\
\text { MS. Rawlinson B 467, p. 52r }\end{array}$ \\
\hline $\begin{array}{l}\text { mân geirch "small } \\
\text { oats" }\end{array}$ & $\begin{array}{l}\text { Culhwch ac } \\
\text { Olwen }\end{array}$ & Oxford, Jesus College MS. 111 (Llyfr Coch Hergest), p. 202v \\
\hline $\begin{array}{l}\text { mân raean "fine } \\
\text { gravel" }\end{array}$ & $\begin{array}{l}\text { Culhwch ac } \\
\text { Olwen }\end{array}$ & $\begin{array}{l}\text { NLW MS. Peniarth } 4 \text { (Llyfr Gwyn Rhydderch, part 2), p. 85v; } \\
\text { Oxford, Jesus College MS. } 111 \text { (Llyfr Coch Hergest), p. 204r }\end{array}$ \\
\hline gwallt mân "fine hair" & Ystoria Dared & $\begin{array}{l}\text { NLW MS. } 3035 \text { (Mostyn 116), p. 9r; NLW MS. Peniarth } 47 \\
\text { part i, p. 10; Cardiff MS. 1.362 (Hafod 1), p. 111r; Oxford, } \\
\text { Jesus College MS. } 111 \text { (Llyfr Coch Hergest), p. 3r; BL MS. } \\
\text { Cotton Cleopatra B V part iii, p. 228r; BL MS. Cotton } \\
\text { Cleopatra B V part iii, p. 229r }\end{array}$ \\
\hline mânwlith "fine dew" & $\begin{array}{l}\text { Ymborth yr } \\
\text { Enaid }\end{array}$ & $\begin{array}{l}\text { NLW MS. Llanstephan } 27 \text { (Llyfr Coch Talgarth), p. 35r; NLW } \\
\text { MS. Llanstephan } 27 \text { (Llyfr Coch Talgarth), p. 39r; NLW MS. } \\
\text { Peniarth 15, p. 46; NLW MS. Peniarth 15, p. 46; NLW MS. } \\
\text { Peniarth 15, p. 51; NLW MS. Peniarth 190, p. 200; NLW MS. } \\
\text { Peniarth 190, p. 215; Oxford, Jesus College MS. 119 (Llyfr } \\
\text { Ancr Llanddewi Brefi), p. 84r; Oxford, Jesus College MS. } 119 \\
\text { (Llyfr Ancr Llanddewi Brefi), p. 89r; Oxford, Jesus College } \\
\text { MS. 20, p. 22v }\end{array}$ \\
\hline $\begin{array}{l}\text { mân } \\
\text { wrychion/mânwrychion } \\
\text { "small sparks" }\end{array}$ & $\begin{array}{l}\text { Ymborth yr } \\
\text { Enaid }\end{array}$ & $\begin{array}{l}\text { NLW MS. Llanstephan } 27 \text { (Llyfr Coch Talgarth), p. 35v; NLW } \\
\text { MS. Llanstephan 27 (Llyfr Coch Talgarth), p. 39r; NLW MS. } \\
\text { Peniarth 15, p. 47; NLW MS. Peniarth 15, p. 51; NLW MS. } \\
\text { Peniarth 190, p. 203; NLW MS. Peniarth 190, p. 215; Oxford, } \\
\text { Jesus College MS. 119 (Llyfr Ancr Llanddewi Brefi), p. 85r; } \\
\text { Oxford, Jesus College MS. } 119 \text { (Llyfr Ancr Llanddewi Brefi), } \\
\text { p. 89r; Oxford, Jesus College MS. 20, p. 24r }\end{array}$ \\
\hline halen mân "fine salt" & Meddyginiaethau & $\begin{array}{l}\text { BL Additional MS. 14,912, p. 18v; Oxford, Jesus College MS. } \\
111 \text { (Llyfr Coch Hergest), p. 232v; BL Additional MS. 14,912, } \\
\text { p. } 17 \mathrm{v}\end{array}$ \\
\hline
\end{tabular}




\begin{tabular}{|c|c|c|}
\hline lludw mân "fine ashes" & Gwasanaeth Mair & Shrewsbury MS. 11, p. 43 \\
\hline $\begin{array}{l}\text { pwdr mân "fine } \\
\text { powder" }\end{array}$ & Meddyginiaethau & $\begin{array}{l}\text { BL Additional MS. 14,912, p. 42v; Cardiff MS. 3.242 (Hafod } \\
\text { 16), p. 86; Oxford, MS. Rawlinson B 467, p. 50r; }\end{array}$ \\
\hline $\begin{array}{l}\text { gwraidd yr ysgall mân } \\
\text { "fine root of thistle(s)" }\end{array}$ & Meddyginiaethau & $\begin{array}{l}\text { BL Additional MS. 14,912, p. 62r; Cardiff MS. } 3.242 \text { (Hafod } \\
\text { 16), p. 95; Oxford, Jesus College MS. } 111 \text { (Llyfr Coch } \\
\text { Hergest), p. 235r; Oxford, MS. Rawlinson B 467, p. 27r; } \\
\text { Oxford, MS. Rawlinson B 467, p. 28r }\end{array}$ \\
\hline \multirow[t]{5}{*}{$\begin{array}{l}\text { mân ysgrybl, } \\
\text { manysgrybl "small } \\
\text { animals" }\end{array}$} & Amlyn ac Amig & Oxford, Jesus College MS. 111 (Llyfr Coch Hergest), p. 277v \\
\hline & $\begin{array}{l}\text { Arwyddion Lloer } \\
\text { Ionawr }\end{array}$ & BL Additional MS. 14,912, p. 82v \\
\hline & Llyfr Iorwerth & $\begin{array}{l}\text { NLW MS. Peniarth } 32 \text { (Y Llyfr Teg), p. 10; NLW MS. Peniarth } \\
32 \text { (Y Llyfr Teg), p. 155; NLW MS. Peniarth } 32 \text { (Y Llyfr Teg), } \\
\text { p. 160; NLW MS. Peniarth } 32 \text { (Y Llyfr Teg), p. 23; NLW MS. } \\
\text { Peniarth 35, p. 77v; NLW MS. Peniarth 35, p. 80r }\end{array}$ \\
\hline & Prif y Lleuad & NLW MS. Peniarth 4 (Llyfr Gwyn Rhydderch, part 2), p. 59r \\
\hline & $\begin{array}{l}\text { Rhinweddau } \\
\text { Bwydydd }\end{array}$ & Oxford, MS. Rawlinson B 467, p. 15r \\
\hline
\end{tabular}

\section{SINGULAR}

\begin{tabular}{|l|l|l|}
\hline \multicolumn{1}{|c|}{ Example } & \multicolumn{1}{|c|}{ Text } & \multicolumn{1}{c|}{ Manuscript } \\
\hline $\begin{array}{l}\text { cyngaf mân "fruit of } \\
\text { agrimony" }\end{array}$ & Meddyginiaethau & $\begin{array}{l}\text { BL Additional MS. 14,912, p. 44v; Cardiff MS. 3.242 (Hafod } \\
\text { 16), p. 69; Cardiff MS. 3.242 (Hafod 16), p. 84; Oxford, } \\
\text { Jesus College MS. 111 (Llyfr Coch Hergest), p. 231v; } \\
\text { Oxford, MS. Rawlinson B 467, p. 52r }\end{array}$ \\
\hline gogr mân "fine sieve" & Llyfr Iorwerth & NLW MS. Peniarth 32 (Y Llyfr Teg), p. 37 \\
\hline $\begin{array}{l}\text { mân gwaith, } \\
\text { manwaith } \\
\text { "insignificant work" }\end{array}$ & $\begin{array}{l}\text { Manawydan (Third } \\
\text { Manch of the }\end{array}$ & $\begin{array}{l}\text { NLW MS. Peniarth 4 (Llyfr Gwyn Rhydderch, part 2), p. } \\
\text { 18v; Oxford, Jesus College MS. 111 (Llyfr Coch Hergest), p. } \\
184 \mathrm{v}\end{array}$ \\
\hline $\begin{array}{l}\text { manwaith "fine/ } \\
\text { delicate work" }\end{array}$ & Penityas & NLW MS. Peniarth 190, p. 253 \\
\hline $\begin{array}{l}\text { mân Ilwdn "minor } \\
\text { animal (in the laws)" }\end{array}$ & Llyfr Iorwerth & NLW MS. Peniarth 32 (Y Llyfr Teg), p. 10 \\
\hline $\begin{array}{l}\text { peth mor fân a'r rhai } \\
\text { hyn "a thing as } \\
\text { insignificant as those" }\end{array}$ & Culhwch ac Olwen & Oxford, Jesus College MS. 111 (Llyfr Coch Hergest), p. 206r \\
\hline
\end{tabular}

\section{ADJECTIVES}




\begin{tabular}{|l|l|l|}
\hline \multicolumn{1}{|c|}{ Example } & \multicolumn{1}{|c|}{ Text } & \multicolumn{1}{c|}{ Manuscript } \\
\hline $\begin{array}{l}\text { mân wynion, } \\
\text { manwynion "small } \\
\text { or fine and white" } \\
(\text { GPC })\end{array}$ & $\begin{array}{l}\text { Ymborth yr } \\
\text { Enaid }\end{array}$ & $\begin{array}{l}\text { NLW MS. Llanstephan 27 (Llyfr Coch Talgarth), p. 36r; NLW MS. } \\
\text { Peniarth 15, p. 47; NLW MS. Peniarth 190, p. 204; Oxford, Jesus } \\
\text { College MS. 119 (Llyfr Ancr Llanddewi Brefi), p. 85r; Oxford, Jesus } \\
\text { College MS. 20, p. 24v }\end{array}$ \\
\hline $\begin{array}{l}\text { manfrith "finely } \\
\text { speckled or } \\
\text { freckled, spotted" } \\
(\text { GPC })\end{array}$ & $\begin{array}{l}\text { Ymborth yr } \\
\text { Enaid }\end{array}$ & $\begin{array}{l}\text { NLW MS. Llanstephan 27 (Llyfr Coch Talgarth), p. 37r; NLW MS. } \\
\text { Peniarth 190, p. 208; Oxford, Jesus College MS. 119 (Llyfr Ancr } \\
\text { Llanddewi Brefi), p. 86v; Oxford, Jesus College MS. 20, p. 26v }\end{array}$ \\
\hline
\end{tabular}

\section{ADVERBS}

\begin{tabular}{|l|l|l|}
\hline \multicolumn{1}{|c|}{ Example } & \multicolumn{1}{c|}{ Text } & \multicolumn{1}{c|}{ Manuscript } \\
\hline $\begin{array}{l}\text { morteru'n fân } \\
\text { "to pound } \\
\text { finely in a } \\
\text { mortar" }\end{array}$ & Campau'r Cennin & $\begin{array}{l}\text { BL Additional MS. 14,912, p. 74v; Cardiff MS. 3.242 (Hafod 16), p. } \\
\text { 65; Oxford, MS. Rawlinson B 467, p. 35v }\end{array}$ \\
\hline $\begin{array}{l}\text { tafellu'n fân } \\
\text { "to slice finely" }\end{array}$ & Meddyginiaethau & $\begin{array}{l}\text { BL Additional MS. 14,912, p. 14v; Oxford, Jesus College MS. 111 } \\
\text { (Llyfr Coch Hergest), p. 232r; Oxford, MS. Rawlinson B 467, p. 23r }\end{array}$ \\
\hline $\begin{array}{l}\text { malu'n fân "to } \\
\text { grind finely" }\end{array}$ & Meddyginiaethau & $\begin{array}{l}\text { BL Additional MS. 14,912, p. 19r; Cardiff MS. 3.242 (Hafod 16), p. } \\
\text { 32; Oxford, MS. Rawlinson B 467, p. 77r }\end{array}$ \\
\hline $\begin{array}{l}\text { briwo'n fân } \\
\text { "to } \\
\text { break/pound } \\
\text { finely" }\end{array}$ & Meddyginiaethau & $\begin{array}{l}\text { BL Additional MS. 14,912, p. 59r; Cardiff MS. 3.242 (Hafod 16), p. } \\
\text { 98; Oxford, MS. Rawlinson B 467, p. 67v; Oxford, Jesus College MS. }\end{array}$ \\
& & $\begin{array}{l}\text { 111 (Llyfr Coch Hergest), p. 234v; Cardiff MS. 3.242 (Hafod 16), p. } \\
\text { 23; Cardiff MS. 3.242 (Hafod 16), p. 27; Cardiff MS. 3.242 (Hafod } \\
\text { 16), p. 33; Oxford, MS. Rawlinson B 467, p. 78v; Oxford, MS. } \\
\text { Rawlinson B 467, p. 84v; Oxford, MS. Rawlinson B 467, p. 89r }\end{array}$ \\
\hline
\end{tabular}

\section{PLURAL}

\section{FIFTEENTH CENTURY [15c]}

mân ddagrau "small tears" (Oxford, Jesus College MS. 23 p. 131, p. 140; Llanstephan 3 p. 456; Oxford, Jesus College MS. 23 p. 137)

drylliau mân "small (broken) pieces, fragments" (Peniarth 23 19r; Peniarth 23 68r, 68r, 91v)

mân adafedd "fine threads" (Llanstephan 3. 455, p. 463; Oxford, Jesus College MS. 23 p. 130, p. 135)

mân ddafnau "small drops" (Llanstephan 3 p. 456; Oxford, Jesus College MS. 23 p. 131)

mân bechodau "minor sins" (Llanstephan 3 p. 451)

\section{MORPHOLOGICAL COLLECTIVE}

manwlith, mân wlith "fine dew" (Oxford, Jesus College MS. 23 p. 131; Llanstephan 3 p. 456)

mân wrychion "fine sparks" (Oxford, Jesus College MS. 23 p. 132, p. 140; Llanstephan 3 p. 459)

mân gasnod "fine threads" (Llanstephan 3. 455; Oxford, Jesus College MS. 23 p. 130)

gwallt melyn mân "fine yellow hair" (Peniarth 263 col. 27)

\section{ADJECTIVES}

manfrith "finely speckled" (Oxford, Jesus College MS. 23 p. 135)

manwynion "small or fine and white" (Oxford, Jesus College MS. p. 133; Llanstephan 3 p. 459)

\section{A HISTORICAL CORPUS OF THE WELSH LANGUAGE 1500-1850}

PLURAL

[see website for the abbreviations]

"small"

mân draethau "small beaches" (NLW 17B: LlGO 17 220. 10)

mân gyrtiau (spelled gyrtie in the text) "small courts" (poetry) (Pen. 218: Wtreswr 348)

mân drefi "small towns" (RhY 13. 14)

mân bryfed "small worms" (poetry) (TCh 2608)

ydau mân (text yde) "fine grains" (poetry) (BWB 108-2 53) 
tameidiau mân (text tameidie) "little pieces" (poetry) (BWB 370-1 49)

dryll(i)au mân "small (broken) pieces, fragments" (NLW 13075B: YAL 77v. 13; YK 94r. 8; YK 131r. 17)

"insignificant"

meirw fawr a mân "the great and small/insignificant dead (people)" (poetry) (BWB 370-1 34)

mân aerod "petty heirs" (poetry) (BLl 1532)

codau mân (text code) "small bags" (poetry) (BLl 1538)

mân-ladron "petty thieves" (GBC 19.25)

mân angheuod "minor deaths" (GBC 69. 13)

Na'r hôll Ddynion, mân a mawrion "nor all men, small and great" (poetry) (LlGM 22. 6)

mân bethau "small things" (poetry) (TCh 1310)

\section{MORPHOLOGICAL COLLECTIVE}

mân wlith "fine dew" (poetry) (BLl 1809)

SINGULAR, +COMPONENT STRUCTURE

halen gwynn mân "fine white salt" (RhY 5. 20)

can mân "fine white flour" (TN Huet Dat. 18 13)

\section{MODERN WELSH [CEG]}

PLURAL

(' $x 2$ ' etc. denote multiple tokens in the corpus)

"small"

mân gwmnïau "small companies"

mân fryniau a dolydd "small hills and meadows"

cerrig mân/mân gerrig "small stones, pebbles"

mân frychau "small spots"

mân anghysonderau "small inconsistencies"

mân dyddynnod "small homesteads/farms"

mân bentrefi "small villages"

oriau mân (y bore) x 15 "small hours (of the morning)"

cymylau mân "small clouds"

dannedd mân "small teeth"

tonnau mân "small waves"

gronynnau mân "small grains"

mân deloriaid "small woodpeckers"

llythrennau mân, mân "small, small letters"

mân doeon "small canopies"

mân weithdai "small workshops"

y cynadleddau mawr a mân "the large and small conferences"

tatws mân "small potatoes"

mân raeadrau "small waterfalls"

mân draethodau "small essays"

nentydd mân "small rivers"

brigau mân "small twigs"

gwladwriaethau mân a mawr "small and large nations"

mân weithgareddau "small activities"

mân ffermydd "small farms"

mân greaduriaid "small creatures"

stribedi mân x 2 "small strips"

darnau mân "small pieces"

plant mân "small children"

mân newidiadau x 3 "small changes"

mân streiciau "small strikes"

rhai mân iawn yw hadau lawnt "lawn seeds are very small (ones)"

"unimportant; minor"

mân swyddi x 2 "minor jobs"

mân dyddynwyr "small farmers, smallholders" 
mân droseddwyr "minor criminals" mân betheuach "unimportant things" mân straeon "small/short stories" mân benaethiaid "minor chiefs" mân gytundebau "minor agreements" mân jobsus "minor jobs" mân ddefodau'r swydd "little customs of the job" mân wŷr "insignificant men, little men" mân frenhinoedd "petty kings" mân foneddigion "petty nobles" mân feirniaid "petty judges" mân feirdd "poets of lowly status, inferior poets" mân esgusion "petty excuses" mân fynachod "minor monks" mân wallau "minor errors" mân wladwriaethau "petty kingdoms" troseddau mawr a mân "major and minor crimes"

\section{MORPHOLOGICAL COLLECTIVE}

eithin mân "small/fine gorse" adar mân x 2/adar mawr a mân "small birds"/"big and small birds" mân lwch "fine dust" (or "unimportant")

mân us "small husks, fine chaff"

po fanaf yr had, manaf y pridd "the finer the seed, the finer the soil"

\section{SINGULAR, +COMPONENT STRUCTURE}

glaw mân x 5 "fine rain, drizzle" newid mân x 2 "small change" eira mân x 2 "fine snow" arian mân "small change"

\section{SINGULAR}

genau mân "small mouth" mân greadur "small creature"

print mân/print manach/er mor fân oedd y print "fine print"/"finer print"/"although the print was so fine" teip mân "small type (in printing)"

crib mân x 2 "fine comb" rhwyd fân x 2 "fine net" y mân ysbigod bonheddig "the noble little spigot (?)" (spigot seems to refer to a person here and the context suggests belittlement or pejorativeness)

\section{$\underline{\text { ADVERB }}$}

torri'n fân "to tear finely (of paper)" a cherddodd yn fân ac yn fuan "she walked elegantly(?) and quickly" malu'n fân x 2 "to grind finely"

\section{VERBAL NOUNS}

mân siarad x 4 "(to) small talk" mân sôn "(to) murmur, grumble" mân ladrata "(to) pilfer" 